Pacific Northwest

National Laboratory

Operated by Battelle for the

U.S. Department of Energy

\title{
Potential Groundwater Recharge from the Infiltration of Surface Runoff in Cold and Dry Creeks, Phase 2
}

SR Waichler

December 2005

Prepared for the U.S. Department of Energy

under Contract DE-AC05-76RL01830 


\title{
DISCLAIMER
}

This report was prepared as an account of work sponsored by an agency of the United States Government. Neither the United States Government nor any agency thereof, nor Battelle Memorial Institute, nor any of their employees, makes any warranty, express or implied, or assumes any legal liability or responsibility for the accuracy, completeness, or usefulness of any information, apparatus, product, or process disclosed, or represents that its use would not infringe privately owned rights. Reference herein to any specific commercial product, process, or service by trade name, trademark, manufacturer, or otherwise does not necessarily constitute or imply its endorsement, recommendation, or favoring by the United States Government or any agency thereof, or Battelle Memorial Institute. The views and opinions of authors expressed herein do not necessarily state or reflect those of the United States Government or any agency thereof.

\author{
PACIFIC NORTHWEST NATIONAL LABORATORY \\ operated by \\ BATTELLE \\ for the \\ UNITED STATES DEPARTMENT OF ENERGY \\ under Contract DE-AC05-76RL01830
}

Printed in the United States of America
Available to DOE and DOE contractors from the Office of Scientific and Technical Information,
P.O. Box 62, Oak Ridge, TN 37831-0062;
ph: (865) 576-8401
fax: $(865) 576-5728$
email: reports@adonis.osti.gov

\footnotetext{
Available to the public from the National Technical Information Service, U.S. Department of Commerce, 5285 Port Royal Rd., Springfield, VA 22161 ph: (800) 553-6847 fax: $(703) 605-6900$ email: orders@ntis.fedworld.gov online ordering: http://www.ntis.gov/ordering.htm
}

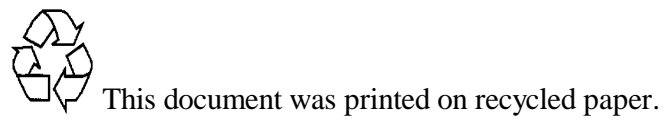




\section{Potential Groundwater Recharge from the Infiltration of Surface Runoff in Cold and Dry Creeks, Phase 2}

SR Waichler

December 2005

Prepared for

Pacific Northwest National Laboratory

Richland, Washington 99352 


\section{Summary}

Runoff (streamflow) from Cold and Dry Creeks was studied as part of a larger effort to evaluate natural recharge to the Hanford Site. Natural recharge to the Site can take the form of direct infiltration of precipitation, lateral inflow of groundwater, and infiltration of streamflow. This report is concerned with the streamflow pathway and considers both historical runoff events and probabilistic extreme events. The observed runoff events were used to fit models of runoff generation, hydrograph shape, and channel infiltration. The models were then used to estimate the magnitude and location of potential recharge from several design storm events based on previous studies of maximum precipitation probability.

The Cold and Dry Creek watersheds were divided into upper, middle, and lower basins, based on the U.S. Geological Survey stream gauge locations described by Dinicola (1997). The upper basins are the primary areas of runoff generation, while the middle and lower basins are areas of infiltration. Hourly weather data and 15-minute streamflow data from January 1995, a period of significant runoff, were used to evaluate the meteorological conditions of the relatively rare runoff generation and to fit and calibrate the models. Frozen ground and melting snow appeared to play important roles in the runoff generation. Hydrographs of Cold and Dry Creeks indicated rapid cresting of streamflows and subsequent rapid recession, with 8 distinct events in Cold Creek. For each runoff event, the duration, volume, and volume of the causative precipitation were tabulated. Curve numbers were computed using the Soil Conservation Service method. A linear relationship between precipitation duration and streamflow duration was also derived. The curve numbers and duration relationship were subsequently used to estimate runoff and hydrograph shape from the design storms of maximum precipitation. A firstorder decay model was fit to the observed streamflows at the upper and lower Cold Creek gauges and used to estimate the spatial pattern of infiltration of streamflow (recharge) resulting from the design storms. The double-triangle hydrograph model was also fit to the data and used to complete the characterization of runoff from the design storms.

Four hypothetical rainfall events (design storms) were used to drive the runoff and infiltration models: 1) 4.6 inches over 6 hours, 2) 1.61 inches over 24 hours, 3) 2.16 inches over 3 days, and 4) 2.71 inches over 7 days. The first value is the "probable maximum precipitation" from Skaggs and Walters (1981), and the latter three values from Wigmosta and Guensch (2005) correspond to a return period of 100 years. For comparison, the largest rainfall event during January 1995 was 1.02 inches over approximately 3 days. Combined Cold and Dry Creek recharge volumes for the 100-year rainfall events were 7,700 ac-ft, 11,700 ac-ft, and $15,900 \mathrm{ac}-\mathrm{ft}$, respectively. These recharge volumes are 7 to 14 times the average annual recharge rate for surface runoff estimated by Dinicola (1997), and fall between two estimates of direct recharge from infiltrating rainfall and snowmelt for the entire Hanford Site: 6,680 ac-ft/y (Fayer and Walters 1995) and 14,467 ac-ft/y (Jacobsen and Freshley 1990). In Cold Creek, simulated streamflow and recharge volumes were largest just above the lower gage. In Dry Creek, simulated runoff volumes were largest at the upper gage, and recharge volumes are greatest in the ponding area downstream from the lower gage. 


\section{Contents}

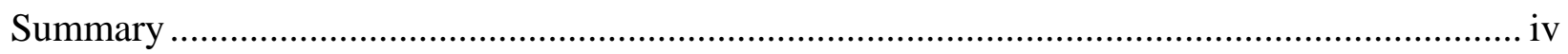

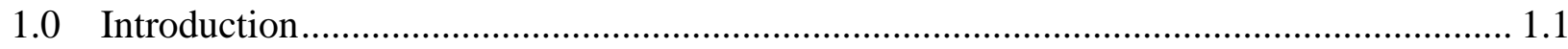

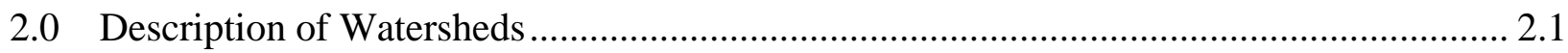

3.0 January 1995 Storm and Runoff Events ....................................................................... 3.1

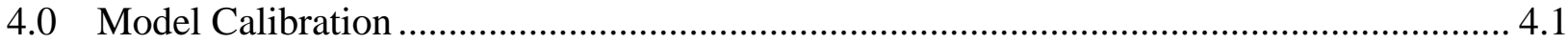

4.1 Channel Infiltration Equation ..............................................................................

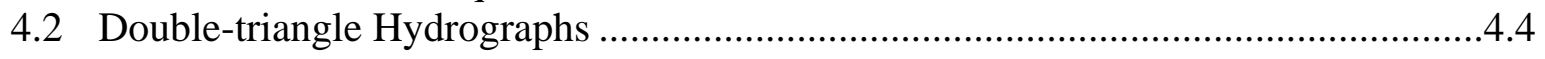

$5.0 \quad$ Design Storm Events.............................................................................................. 5.1

5.1 Precipitation and Streamflow Generation................................................................

5.2 Groundwater Recharge from Channel Infiltration ....................................................5.2

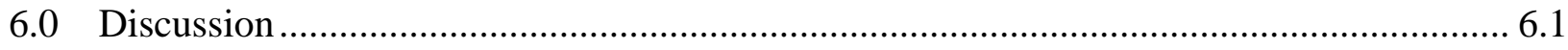

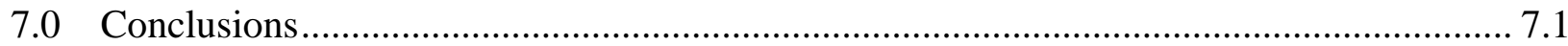

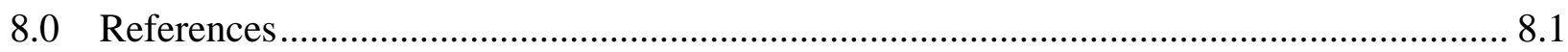

Appendix: Additional Project Data..................................................................................... A-1 


\section{Figures}

$1 \quad$ Location of Subwatersheds and Stream Gages in the Study Area.................................1.1

2 Precipitation, Air Temperature, and Streamflow January 7-12, 1995 ............................2.2

3 Precipitation, Air Temperature, and Streamflow, January 13-15, 1995 ..........................3.3

$4 \quad$ Precipitation, Air Temperature, and Streamflow, January 28-31, 1995 .............................

$5 \quad$ Rainfall and Streamflow Durations for All Basin Events, January 1995 ............................

$6 \quad$ Cold Creek Runoff Volumes and Simple Linear Regression Model.................................4.3

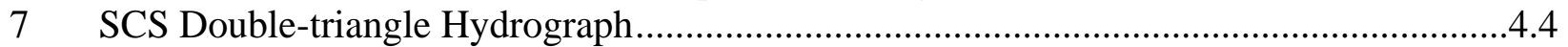

8 Observed and Fitted Double-Triangle Hydrographs, Selected Runoff Events ...................4.5

9 Runoff, Recharge, and Peak Flow vs. Distance.........................................................

\section{Tables}

1 Subwatershed Evaluations and Areas in Upper Cold and Dry Creek Basins ...................2.1

2 Storm Events and SCS Curve Mumbers During January 1995 …...................................5.5

3 Runoff Events for Calibrating Channel Infiltration Model..........................................4.2

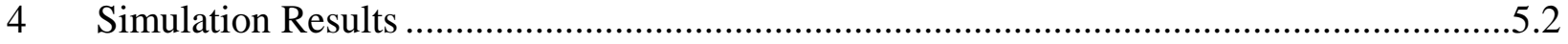




\section{Acronyms}

$\begin{array}{ll}\text { ALE } & \text { Arid Lands Ecology Reserve } \\ \text { D } & \text { duration } \\ \text { HMS } & \text { Hanford Meteorological Station } \\ \text { PMP } & \text { probable maximum precipitation } \\ \text { Qp } & \text { peak flow rate } \\ \text { SCS } & \text { Soil Conservation Service } \\ \text { USGS } & \text { U.S. Geological Survey }\end{array}$




\subsection{Introduction}

The hydraulic gradient in the upper unconfined aquifer is a key factor in determining the fate and transport of subsurface contaminants at the Hanford Site. This gradient is influenced by the location and amount of recharge from the ground surface. Natural recharge to the aquifer results from direct infiltration of rainfall and snowmelt and from the infiltration of surface runoff, primarily in ephemeral streams (Dinicola 1997). Most of the groundwater recharge from streamflow is thought to occur in Cold and Dry Creeks, located in the western portion of the Hanford Site (Figure 1). Annual recharge from this source was estimated by Dinicola (1997) to be 1,175 ac-ft/y. This source of groundwater recharge is of particular interest because of its role in maintaining the west-east hydraulic gradient in the unconfined aquifer between runoff events and temporarily increasing the gradient immediately after such events.

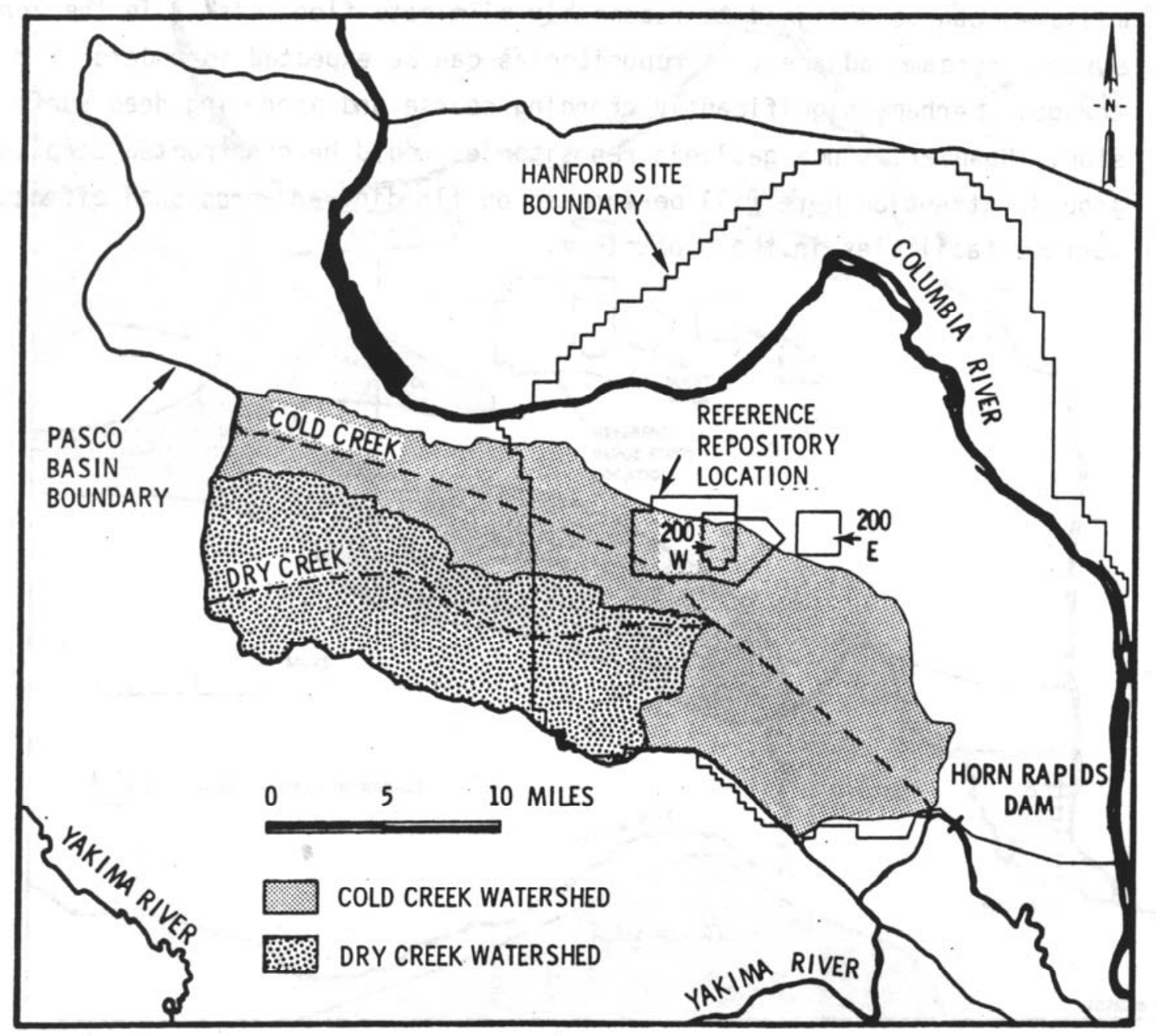

Figure 1. Location of Subwatersheds and Stream Gages in the Study Area 
In Phase 1 of this study, Wigmosta and Guensch (2005) estimated potential runoff from the Cold and Dry Creek basins using two hypothetical precipitation events and the Soil Conservation Service (SCS) curve number approach (Soil Conservation Service 1972). For the probable maximum precipitation over 6 hours (4.6 inches, [Skaggs and Walters 1981]), they estimated a runoff volume of 7 to 11 times the annual recharge, depending on assumed curve number. A storm with a 100-year recurrence interval and 7-day duration had an estimated precipitation of 2.71 inches. and produced 3 to 5 times the annual recharge. The Phase 1 report concluded with a list of the key assumptions underlying the SCS curve number method and its application to Cold and Dry Creeks.

The purpose of this phase 2 study was to extend the work of Wigmosta and Guensch (2005). First, weather and high-resolution runoff data from storm events during January 1995 were analyzed in greater detail. Next, a simple runoff and recharge model was constructed from the SCS curve number and hydrograph methods and using an exponential-decay channel infiltration equation proposed by Lane et al. (1985). The model was then used to estimate the magnitude and location of potential recharge from several design storm events. A list of Phase 2 project files and directories are provided in the Appendix. 


\subsection{Description of Watersheds}

The Cold and Dry Creek basins are defined by basalt ridges trending East-West, with the upper portions of the watersheds originating in the Yakima Firing Range and the lower portions lying in the Arid Lands Ecology Reserve (ALE). The upper elevations exceed $4000 \mathrm{ft}$, while the lower elevations near State Highway 240 are approximately $650 \mathrm{ft}$. This study was primarily concerned with four subwatersheds and corresponding U.S. Geological Survey (USGS) streamflow gages: 1) the area above Upper Cold Creek gage, 2) the area between Upper Cold and Lower Cold gages, 3) the area above Upper Dry Creek gage, and 4) the area between Upper Dry Creek and Lower Dry Creek gages (Figure 1, Table 1). For convenience, the areas above the upper gages are referred to as the upper basins, the areas between the gages are called the middle basins, and the areas downstream of the lower gages are called the lower basins. Stream reaches are similarly referred to as upper, middle, and lower.

Table 1. Subwatershed Evaluations and Areas in Upper Cold and Dry Creek Basins

\begin{tabular}{|c|c|c|c|c|c|c|c|c|}
\hline Subwatershed & $\begin{array}{l}\text { Corresponding } \\
\text { Gaging Station }\end{array}$ & $\begin{array}{l}\text { Dinicola (1997) } \\
\text { Subwatersheds }\end{array}$ & $\begin{array}{l}\text { Min } \\
\text { Elev }\end{array}$ & $\begin{array}{c}\text { Mean } \\
\text { Elev }\end{array}$ & $\begin{array}{l}\text { Max } \\
\text { Elev }\end{array}$ & $\begin{array}{l}\text { Number } \\
\text { GIS } \\
\text { Gridcells }\end{array}$ & $\begin{array}{c}\text { Area from } \\
\text { GIS } \\
\text { Coverage }\end{array}$ & $\begin{array}{c}\begin{array}{c}\text { Area } \\
\text { from }\end{array} \\
\text { Dinicola } \\
\text { (1997) }\end{array}$ \\
\hline & & & (ft) & (ft) & (ft) & & $\left(\mathrm{mi}^{2}\right)$ & $\left(\mathrm{mi}^{2}\right)$ \\
\hline Upper Cold & Upper Cold & COLD4 + COLD3 & 1428 & 2553 & 4108 & 71903 & 28.8 & 28.6 \\
\hline Middle Cold & Lower Cold & COLD2 & 942 & 1654 & 2838 & 29740 & 11.9 & 10.7 \\
\hline Lower Cold & & COLD1 & & & & & & \\
\hline Upper Dry & Upper Dry & DRY4 & 1109 & 2154 & 4203 & 156614 & 62.7 & 56.9 \\
\hline Middle Dry & Lower Dry & DRY3 + DRY2 & 663 & 1657 & 3648 & 166421 & 66.7 & 64.3 \\
\hline Lower Dry & & DRY1 & & & & & & \\
\hline
\end{tabular}

Downstream of the lower gages, no runoff generation from local uplands has been observed, but channel characteristics in these areas are of interest for infiltration of flows generated in the middle and upper basins. More information about the stream gaging stations can be found in Dinicola (1997). A field reconnaissance to all four subwatersheds and selected locations along the lower reaches was made on August 24, 2001 (with the exception of Upper Cold Creek, for which private land access was not available).

In Upper Cold Creek, soils are thin and runoff generation is more frequent than in Upper Dry Creek, which has deeper soils and more opportunity for tributary flow to infiltrate before reaching the main channel (Dinicola 1997). Alluvium thickness and channel infiltration potential both increase in Upper Cold Creek from approximately 1 mile upstream of Lower Cold gage down to the broad, flat valley that parallels Highway 240. The Lower Cold gage is located 50 yards north of the Highway 24 crossing. In Dry Creek, alluvium and infiltration potential appear to greatly increase at the Upper Dry gage, where the channel enters a much wider valley. Upper Dry gage is located 50 yards east of the Highway 241 bridge. For about a mile above Lower Dry gage, the channel is deeply incised, with walls 10 yards high and a distance across of about 40 yards. Lower Dry gage is located immediately downstream of 
Rattlesnake Spring, which produces perennial flow of about 0.5 cfs (Dinicola 1997). The perennial flow supports a vibrant riparian community that fills the channel. The perennial flow is completely infiltrated into the Dry Creek bed at a point about one-quarter mile upstream of the Benson ranch site. 


\subsection{January 1995 Storm and Runoff Events}

Model design and calibration in this study were based on hourly weather data and 15-minute streamflow data from January 1995. Three periods of January 1995 experienced relatively large rainfall and runoff (Figures 2-4). Air temperatures were close to freezing during part of the month, and Dinicola noted that frozen ground and melting snow appeared to play a role in producing runoff during these events ${ }^{1}$. Individual storm events of corresponding precipitation and runoff were defined for modeling purposes (Table 2).

The hydrographs indicated very fast arrival and cresting of the streamflows suggesting powerful bores surging down channel. One flow at Lower Dry Creek shot up from its tiny perennial flow to $167 \mathrm{cfs}$ in only 15 minutes, with the peak flow of $203 \mathrm{cfs}$ occurring just onehalf hour later (January 10, 1995, Figure 2). Recessions were rapid as well, with flows at Lower Cold Creek gage often decreasing to half the peak rate within a couple hours and to essentially zero within 6 hours.

Cold Creek followed a regular pattern of larger flows at the upper gage and lower flows at the lower gage. Lower Cold flows commence sharply a short time after the rise at Upper Cold Creek gage, suggesting that most if not all flow recorded at Lower Cold Creek gage originated as upper basin rather than middle basin runoff. This led to an assumption of no lateral inflow for the purposes of calibrating the channel infiltration model described in the next section.

In contrast, Dry Creek flows were minimal at the Upper Dry Creek gage but substantial at the Lower Dry gage. No flows were recorded at Upper Dry Creek in the digital dataset supplied by the USGS for January 1995. However, Dinicola witnessed flows up to 3 cfs at Upper Dry Creek gage, so data recording may have been inadequate. Also, the channel bed at Upper Dry Creek gage is relatively wide and free of vegetation, suggesting that significant flows do occur there. Five events were defined at Lower Dry Creek, and all were smaller than corresponding flows at Lower Cold Creek gage, even though the total area in Dry Creek is 68 percent larger than Cold Creek.

For each runoff event, start and end times, duration, and volume in basin area-inches were tabulated (Table 2). Corresponding times and depths for the presumed causative precipitation were also noted. Hourly precipitation measurements at several meteorological stations, corresponding lapse rates, and mean basin elevations were used to estimate basin average precipitation for each event. Basin average precipitation estimates using the various lapse rates are variable, and a decision was made to use the Hanford Meteorological Station (HMS) point measurements for the rest of the analysis.

\footnotetext{
${ }^{1}$ Email communication of field notes, 2001.
} 


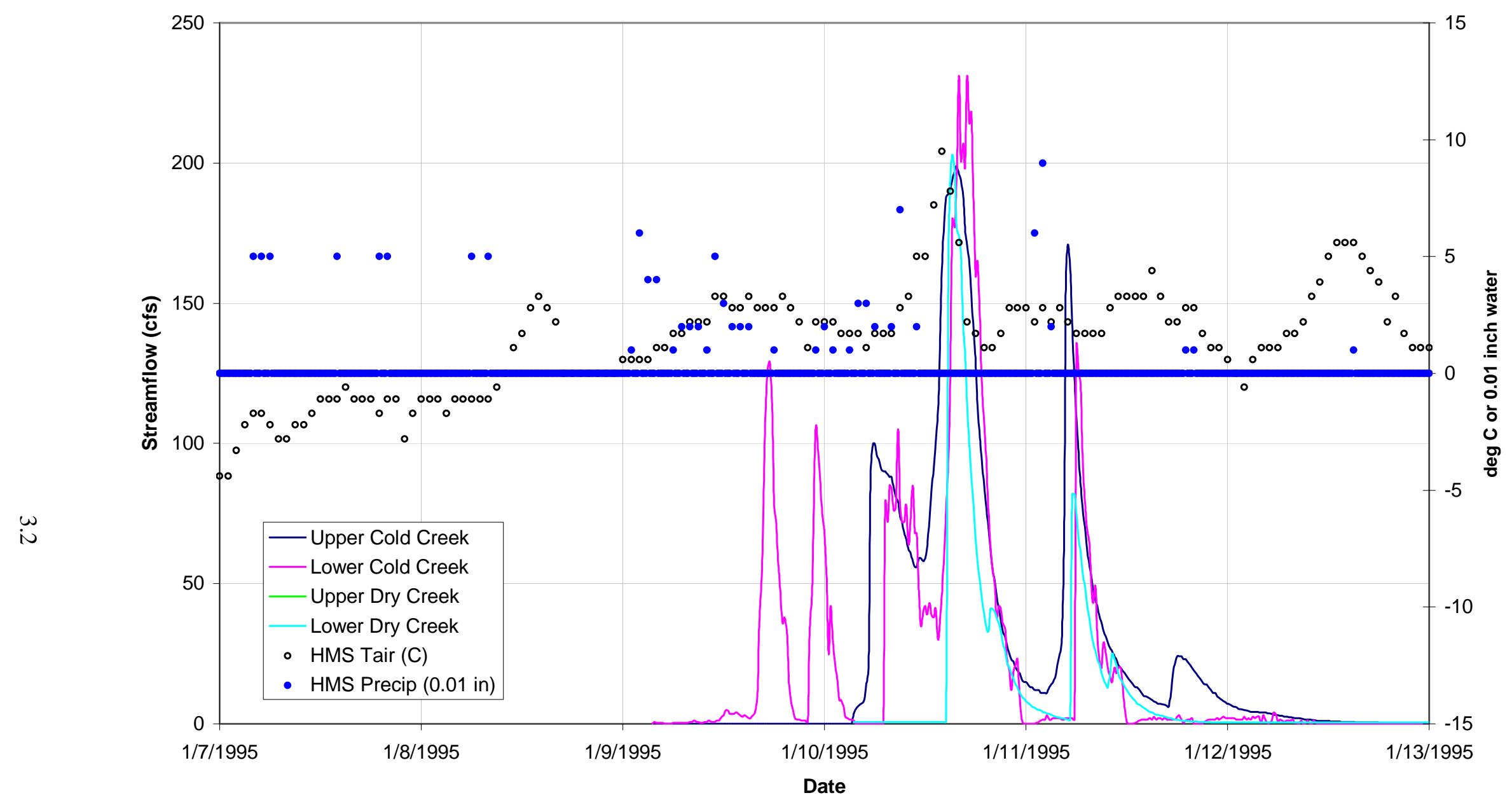

Runoff events: $\quad$ UC1, LC1, LD1 UC2, LC2, LD1

Figure 2. Precipitation, Air Temperature, and Streamflow January 7-12, 1995 


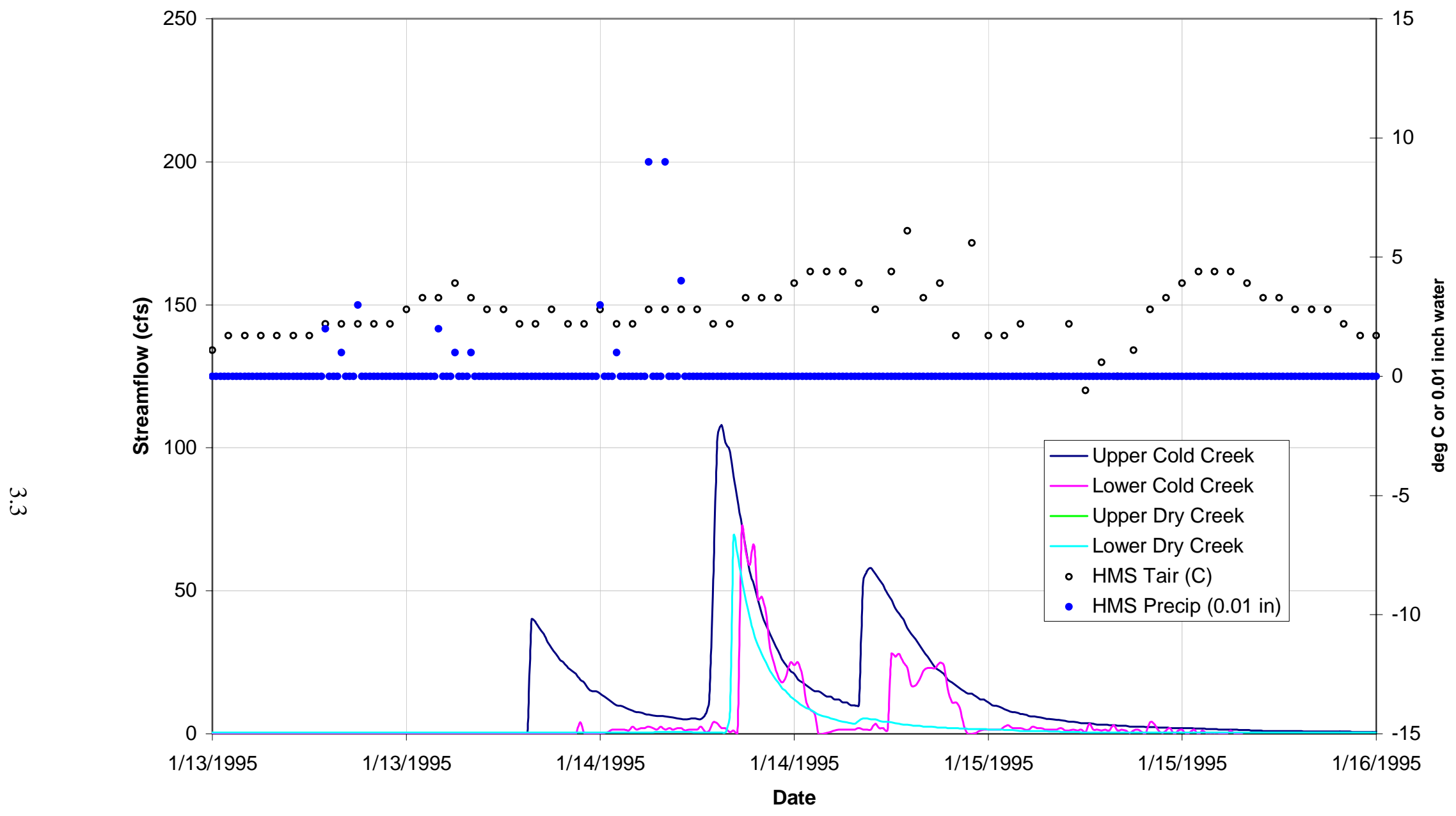

Runoff events: $\quad$ UC3, LC6 UC4, LC3, LD3 UC8, LC7

Figure 3. Precipitation, Air Temperature, and Streamflow, January 13-15, 1995 


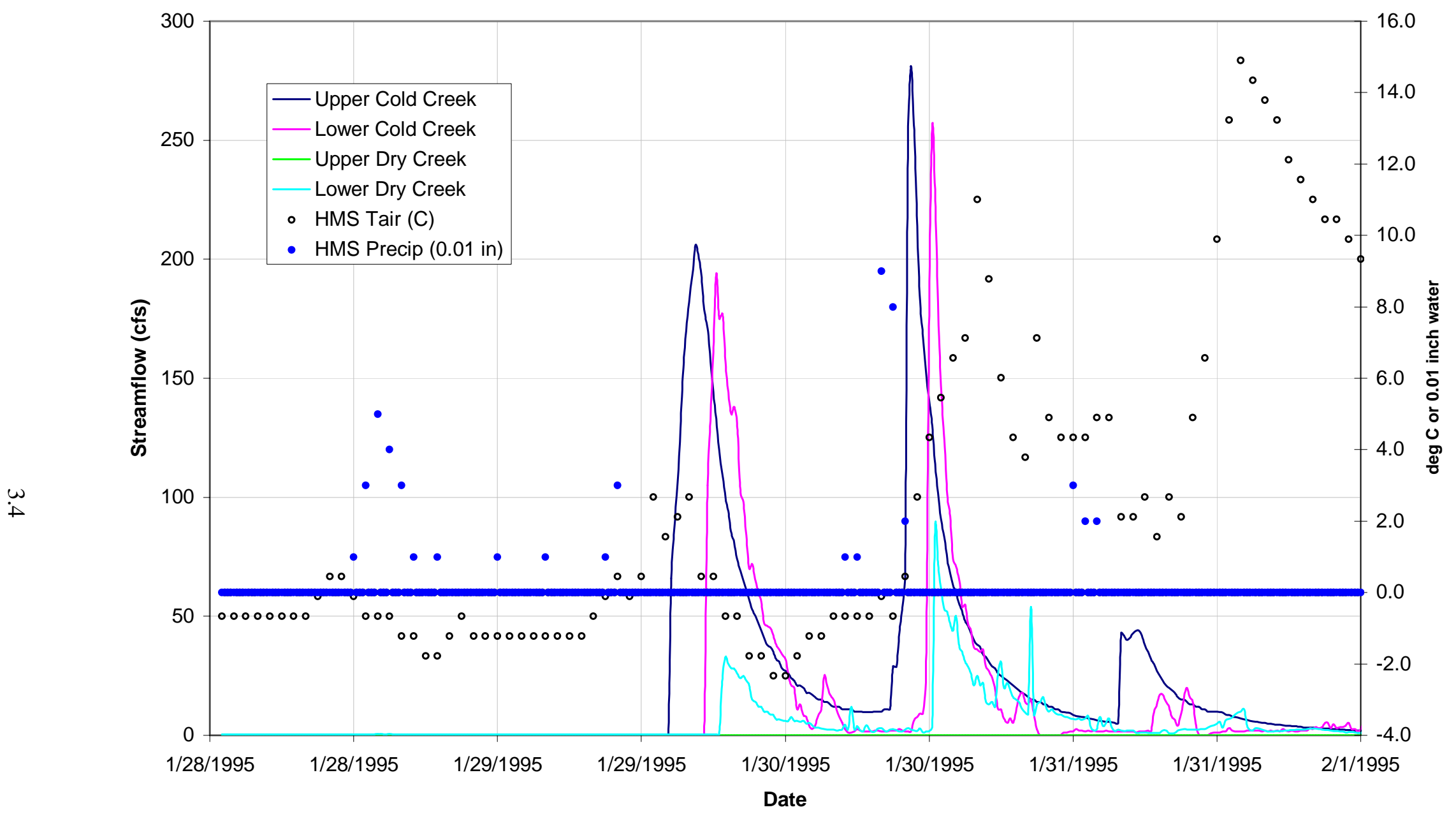

Runoff events: UC5, LC4, LD4 UC6, LC5, LD5 UC7, LC8

Figure 4. Precipitation, Air Temperature, and Streamflow, January 28-31, 1995 
Table 2. Storm Events and SCS Curve Numbers During January 1995

\begin{tabular}{|c|c|c|c|c|c|c|c|c|c|c|c|c|c|c|c|}
\hline \multirow[t]{2}{*}{ Basin Events } & \multicolumn{7}{|c|}{ Precipitation } & \multicolumn{4}{|c|}{ Streamflow } & \multicolumn{4}{|c|}{ Curve Numbers } \\
\hline & Begin time & End time & Hours & \begin{tabular}{|c|} 
HMS \\
Precip \\
(in)
\end{tabular} & \begin{tabular}{|c|} 
EOC - \\
RMTN \\
Lapse1 \\
Precip \\
(in) \\
\end{tabular} & \begin{tabular}{|c|} 
HMS - \\
RMTN \\
Lapse2 \\
Precip \\
(in)
\end{tabular} & $\begin{array}{c}\text { HMS - } \\
\text { EOC } \\
\text { Lapse3 } \\
\text { Precip } \\
\text { (in) }\end{array}$ & Begin time & End time & Hours & $\begin{array}{l}\text { Flow } \\
\text { (in) }\end{array}$ & $\begin{array}{c}\mathrm{CN}, \\
\text { HMS } \\
\text { precip }\end{array}$ & \begin{tabular}{c|}
$\mathrm{CN}$, \\
Lapse1 \\
precip
\end{tabular} & \begin{tabular}{|c|} 
CN, \\
Lapse2 \\
precip
\end{tabular} & \begin{tabular}{|c|} 
CN, \\
Lapse3 \\
precip
\end{tabular} \\
\hline Upper Cold Cr. 1 & 1/7/1995-04:00 & 1/10/1995-11:00 & 79 & 1.02 & 0.49 & 0.54 & 0.95 & 1/10/1995-03:30 & 1/11/1995-02:30 & 23 & 0.095 & 80 & 93 & 91 & 82 \\
\hline Upper Cold Cr. 2 & 1/11/1995-01:00 & 1/11/1995-03:00 & 3 & 0.17 & 0.14 & 0.12 & 0.24 & 1/11/1995-02:45 & 1/11/1995-17:00 & 14.25 & 0.031 & 97 & 98 & 98 & 95 \\
\hline Upper Cold Cr. 3 & 1/13/1995-07:00 & 1/13/1995-16:00 & 10 & 0.100 & 0.15 & 0.12 & 0.5 & $\mid 1 / 13 / 1995-19: 45$ & 1/14/1995-06:15 & 10.5 & 0.00844 & 98 & 96 & 97 & 84 \\
\hline Upper Cold Cr. 4 & 1/14/1995-00:00 & 1/14/1995-05:00 & 6 & 0.26 & 0.15 & 0.18 & 0.08 & 1/14/1995-06:30 & 1/14/1995-16:00 & 9.5 & 0.019 & 94 & 97 & 96 & 99 \\
\hline Upper Cold Cr. 5 & 1/28/1995-12:00 & $\mid 1 / 29 / 1995-10: 00$ & 23 & 0.24 & 0.25 & 0.24 & 0.4 & 1/29/1995-14:30 & 1/30/1995-08:45 & 18.25 & 0.058 & 97 & 96 & 97 & 93 \\
\hline Upper Cold Cr. 6 & 1/30/1995-05:00 & 1/30/1995-10:00 & 6 & 0.21 & 0.16 & 0.14 & 0.39 & 1/30/1995-09:00 & 1/31/1995-03:45 & 18.75 & 0.049 & 97 & 98 & 99 & 92 \\
\hline Upper Cold Cr. 7 & 1/31/1995-00:00 & 1/31/1995-02:00 & 3 & 0.07 & 0.05 & 0.05 & 0.03 & 1/31/1995-04:00 & 2/1/1995-00:00 & 19.75 & 0.013 & 99 & 99 & 99 & 100 \\
\hline Mean (1) & & & & & & & & & & & & 96 & 97 & 97 & 93 \\
\hline Upper Cold Cr. Comp. 1,2 & 1/7/1995-04:00 & 1/11/1995-03:00 & 96 & 1.19 & 0.63 & 0.66 & 1.19 & 1/10/1995-03:30 & 1/11/1995-17:00 & 37.25 & 0.125 & 79 & 91 & 90 & 79 \\
\hline Upper Cold Cr. Comp. 3,4 & 1/13/1995-07:00 & 1/14/1995-05:00 & 23 & 0.36 & 0.3 & 0.3 & 0.58 & $\mid 1 / 13 / 1995-19: 45$ & 1/14/1995-16:00 & 20 & 0.028 & 92 & 93 & 93 & 85 \\
\hline \multirow[t]{2}{*}{ Upper Cold Cr. Comp. 5,6,7 } & 1/28/1995-12:00 & 1/31/1995-02:00 & 74 & 0.52 & 0.46 & 0.43 & 0.82 & 1/29/1995-14:30 & 2/1/1995-00:00 & 56.75 & 0.121 & 93 & 94 & 95 & 86 \\
\hline & & & & & & & & & & & & & & & \\
\hline Lower Cold Cr. 1 & 1/7/1995-04:00 & 1/10/1995-11:00 & 79 & 1.02 & 0.61 & 0.55 & 0.81 & 1/10/1995-07:15 & 1/10/1995-23:30 & 16.25 & 0.207 & 66 & 77 & 78 & 71 \\
\hline Lower Cold Cr. 2 & 1/11/1995-01:00 & 1/11/1995-03:00 & 3 & 0.17 & 0.16 & 0.13 & 0.23 & 1/11/1995-06:00 & 1/11/1995-12:00 & 6 & 0.041 & 92 & 93 & 94 & 90 \\
\hline Lower Cold Cr. 3 & 1/13/1995-07:00 & 1/13/1995-16:00 & 10 & 0.1 & 0.17 & 0.12 & 0.42 & $\mid 1 / 14 / 1995-08: 45$ & 1/14/1995-13:15 & 4.5 & 0.023 & 95 & 92 & 94 & 83 \\
\hline Lower Cold Cr. 4 & 1/28/1995-12:00 & 1/29/1995-10:00 & 23 & 0.24 & 0.27 & 0.24 & 0.36 & 1/29/1995-17:30 & 1/30/1995-11:30 & 18 & 0.106 & 89 & 88 & 89 & 85 \\
\hline \begin{tabular}{|l|} 
Lower Cold Cr. 5 \\
\end{tabular} & 1/30/1995-05:00 & \begin{tabular}{|l|}
$1 / 30 / 1995-10: 00$ \\
\end{tabular} & 6 & 0.21 & 0.18 & 0.14 & 0.34 & 1/30/1995-11:45 & 1/30/1995-21:00 & 9.25 & 0.078 & 90 & 92 & 93 & 85 \\
\hline Mean (1) & & & & & & & & & & & & 91 & 91 & 92 & 84 \\
\hline Lower Cold Comp. 1,2 & 1/7/1995-04:00 & 1/11/1995-03:00 & 96 & 1.19 & 0.77 & 0.68 & 1.04 & 1/10/1995-07:15 & 1/11/1995-12:00 & 22.25 & 0.248 & 63 & 72 & 75 & 66 \\
\hline Lower Cold Comp. 4,5 & 1/28/1995-12:00 & $1 / 31 / 1995-02: 00$ & 74 & 0.45 & 0.45 & 0.38 & 0.7 & $1 / 29 / 1995-17: 30$ & 1/30/1995-21:00 & 22.5 & 0.184 & 82 & 82 & 84 & 74 \\
\hline Lower Dry Cr. 1 & 1/7/1995-04:00 & 1/10/1995-11:00 & 79 & 1.02 & 0.61 & 0.59 & 0.67 & 1/10/1995-14:45 & 1/11/1995-05:15 & 13.75 & 0.016 & 72 & 83 & 83 & 81 \\
\hline Lower Dry Cr. 2 & 1/11/1995-01:00 & \begin{tabular}{|l|}
$1 / 11 / 1995-03: 00$ \\
\end{tabular} & 3 & 0.17 & 0.17 & 0.15 & 0.22 & 1/11/1995-05:30 & $1 / 11 / 1995-20: 30$ & 15 & 0.006 & 95 & 95 & 96 & 93 \\
\hline Lower Dry Cr. 3 & 1/13/1995-07:00 & \begin{tabular}{|l|}
$1 / 13 / 1995-16: 00$ \\
\end{tabular} & 10 & 0.1 & 0.17 & 0.1 & 0.33 & 1/14/1995-08:00 & $1 / 14 / 1995-15: 45$ & 7.75 & 0.004 & 97 & 94 & 97 & 89 \\
\hline Lower Dry Cr. 4 & 1/28/1995-12:00 & 1/29/1995-10:00 & 23 & 0.24 & 0.27 & 0.26 & 0.32 & \begin{tabular}{|l|}
$1 / 29 / 1995-18: 45$ \\
\end{tabular} & 1/30/1995-12:15 & 10 & 0.003 & 92 & 90 & 91 & 89 \\
\hline Lower Dry Cr. 5 & 1/30/1995-05:00 & \begin{tabular}{|l|}
$1 / 30 / 1995-10: 00$ \\
\end{tabular} & 6 & 0.26 & 0.16 & 0.2 & 0.08 & 1/30/1995-12:30 & |1/31/1995-03:45 & 15.25 & 0.007 & 92 & 95 & 94 & 98 \\
\hline Mean (1) & & & & & & & & & & & & 93 & 93 & 93 & 90 \\
\hline Lower Dry Comp. 1,2 & 1/7/1995-04:00 & 1/11/1995-03:00 & 96 & 1.19 & 0.78 & 0.74 & 0.89 & 1/10/1995-14:45 & 1/11/1995-20:30 & 28.75 & 0.022 & 70 & 79 & 80 & 76 \\
\hline Lower Dry Comp. 4,5 & 1/28/1995-12:00 & $1 / 31 / 1995-02: 00$ & 74 & 0.5 & 0.43 & 0.46 & 0.4 & 1/29/1995-18:45 & 1/31/1995-03:45 & 25.25 & 0.010 & 85 & 87 & 86 & 88 \\
\hline Upper Dry Cr. 1 & 1/7/1995-04:00 & 1/10/1995-11:00 & 79 & 1.02 & 0.61 & 0.55 & 0.79 & & & & 0.000 & 66 & 77 & 78 & 72 \\
\hline Upper Dry Cr. 2 & 1/11/1995-01:00 & 1/11/1995-03:00 & 3 & 0.17 & 0.16 & 0.13 & 0.23 & & & & 0.000 & 92 & 93 & 94 & 90 \\
\hline Upper Dry Cr. 3 & 1/13/1995-07:00 & 1/13/1995-16:00 & 10 & 0.1 & 0.17 & 0.12 & 0.41 & & & & 0.000 & 95 & 92 & 94 & 83 \\
\hline Upper Dry Cr. 4 & 1/28/1995-12:00 & 1/29/1995-10:00 & 23 & 0.24 & 0.27 & 0.24 & 0.36 & & & & 0.000 & 89 & 88 & 89 & 85 \\
\hline Upper Dry Cr. 5 & 1/30/1995-05:00 & 1/30/1995-10:00 & 6 & 0.26 & 0.16 & 0.2 & 0.08 & & & & 0.000 & 88 & 93 & 91 & 96 \\
\hline Mean (1) & & & & & & & & & & & & 90 & 91 & 91 & 86 \\
\hline Upper Dry Comp. 1,2 & 1/7/1995-04:00 & 1/11/1995-03:00 & 96 & 1.19 & 0.77 & 0.68 & 1.02 & & & & 0.000 & 63 & 72 & 75 & 66 \\
\hline \multirow[t]{2}{*}{ Upper Dry Comp. 4,5 } & 1/28/1995-12:00 & $\mid 1 / 31 / 1995-02: 00$ & 74 & 0.5 & 0.43 & 0.44 & 0.44 & & & & 0.000 & 80 & 82 & 82 & 82 \\
\hline & \multicolumn{2}{|c|}{ (1) Mean of individual events, excepting the highest and lowest values. } & & & & & & & & & Mean & 87 & 90 & 91 & 85 \\
\hline "Comp." = composite of individual & vents & & & & & & & & & & CoeffDev & 0.12 & 0.08 & 0.08 & 0.10 \\
\hline \multirow{2}{*}{\multicolumn{3}{|c|}{$\begin{array}{l}\text { HMS = Hanford Meteorological Station point measurement. } \\
\text { (source: Computed Fluxes worksheet in cold_dry_flow2.xls) }\end{array}$}} & & & & & & & & & & & & & \\
\hline & & & & & & & & & & & & & & & \\
\hline
\end{tabular}


SCS curve numbers were computed for each of the labeled runoff events (Table 2), using the equation

$$
C N=\frac{1000}{\frac{0.4 P+0.8 Q-\sqrt{0.8 P Q+0.64 Q^{2}}}{0.08}+10},
$$

where $\mathrm{CN}=$ curve number, $\mathrm{P}=$ precipitation (inches), and $\mathrm{Q}=$ runoff (inches). In the case of Lower Cold Creek (middle subwatershed), runoff was assumed to be zero for the purpose of computing the $\mathrm{CN}$ because it appeared that all runoff was generated from the upper subwatershed.

Similarly, curve numbers for Upper Dry Creek were computed assuming no flow. The resulting $\mathrm{CN}$ values were conservatively high in the sense that a marginal increase in precipitation would have resulted in predicted runoff; in reality, a substantial increase in precipitation may have been required to produce runoff. CNs for Lower Dry Creek were computed assuming that all flow originated from that subwatershed (below Upper Dry Creek gage). After discarding the highest and lowest values, mean curve numbers for Upper Cold Creek, Lower Cold Creek, Upper Dry Creek, and Lower Dry Creek were 96, 91, 93, and 90, respectively (Table 2).

For estimating the impact of design storms with the simple modeling approach, both precipitation and streamflow duration had to be decided in advance. Streamflow duration was required to determine the shape of the hydrograph for storm runoff. Observed streamflow durations were plotted and regressed against rainfall duration for the January 1995 events (Figure 5). Although the fit was weak (R-squared=0.40), the linear relationship was used because no better method for determining design duration was available. Rainfall durations of 6 hours, 1 day, 3 days, and 7 days resulted in the following design streamflow durations: 12 hours, 16 hours, 25 hours, and 43 hours, respectively. Streamflow durations that are markedly less than rainfall duration indicate that many hours worth of rainfall may be going to storage before a condition of rainfall excess and runoff generation prevails in the watershed. 


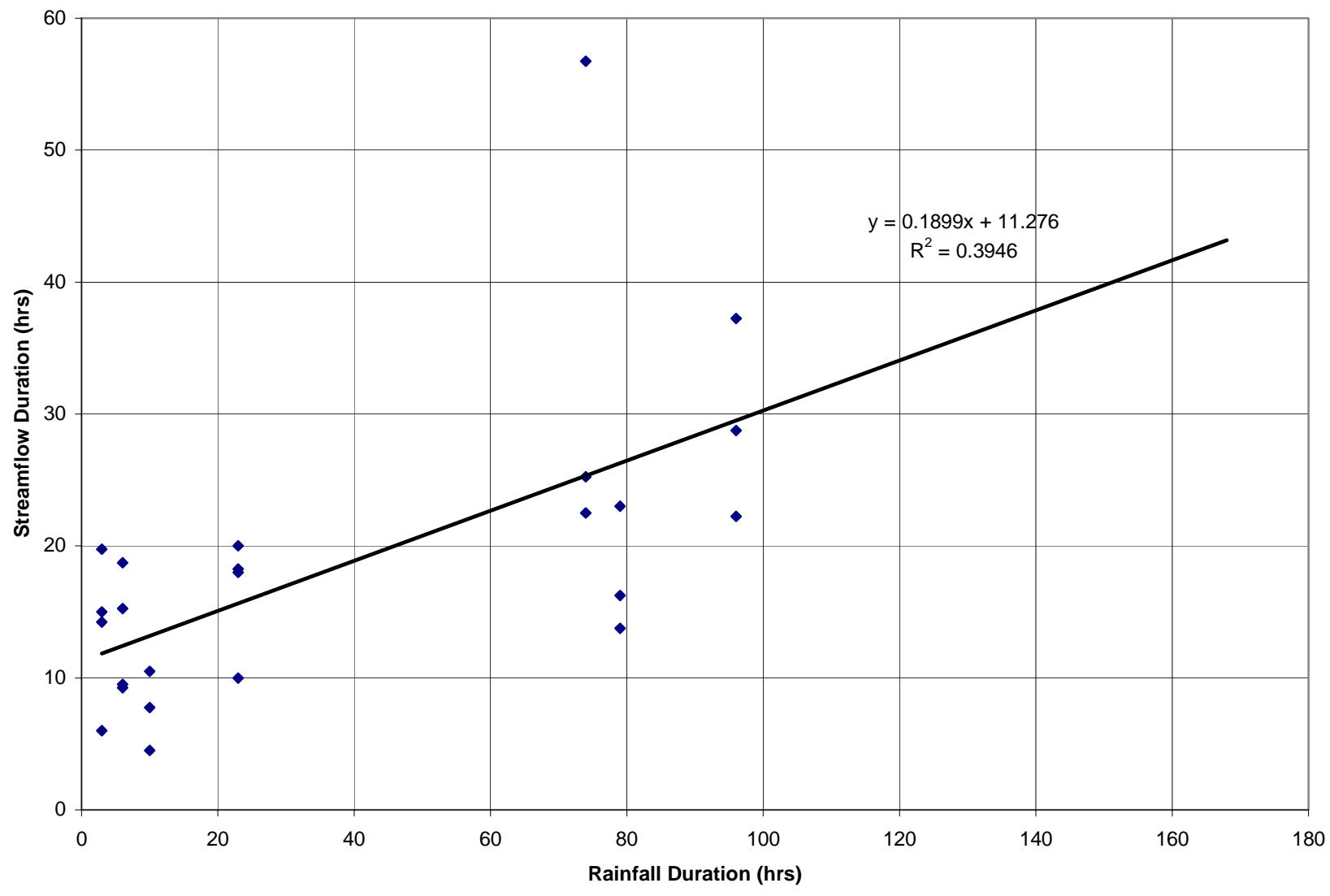

Figure 5. Rainfall and Streamflow Durations for All Basin Events, January 1995 


\subsection{Model Calibration}

The first part of the simple runoff/recharge model used the SCS curve number method to compute total runoff volume. For the second part of the model involving distribution of channel infiltration (groundwater recharge), it was necessary to consider the change in runoff volume along the stream channels. The shape of the hydrograph was also predicted to arrive at estimates of peak flow rates.

\subsection{Channel Infiltration Equation}

Lane et al. (1985) proposed a simple exponential decay model to estimate infiltration and recharge as a function of channel length and width (Equation 16 in Lane et al. 1985):

$$
V_{\text {Out }}=\frac{-c}{k}\left(1-e^{-k w x}\right)+V_{U p} e^{-k x w}+\frac{V_{L a t}}{k x w}\left(1-e^{-k x w}\right)
$$

where Vout $=$ runoff volume at end of a stream reach $\left(\mathrm{m}^{3}\right), x=$ distance from beginning of stream reach $(\mathrm{m}), w=$ stream channel width $(\mathrm{m}), V u p=$ runoff volume at the beginning of the stream reach $\left(\mathrm{m}^{3}\right)$, Vlat $=$ lateral inflow to the stream reach $\left(\mathrm{m}^{3}\right)$, and $c$ and $k$ are coefficients. By lumping parameters and letting $g=-c / k$ and $h=-k x w$, the equation can be simplified to

$$
V_{\text {Out }}=g\left(1-e^{h}\right)+V_{U p} e^{h}-\frac{V_{\text {Lat }}}{h}\left(1-e^{h}\right)
$$

Equation 3 was fitted to the paired hydrographs from Upper Cold Creek and Lower Cold Creek gages (Table 3). Because the fit was poor, and lateral inflow did not appear to be important to flow at Lower Cold Creek, the lateral inflow term (Vlat) was discarded from Equation 3, leading to an equation suitable for simple linear regression:

$$
V_{\text {Out }}=B_{0}+B_{1} V_{U p}
$$

where the intercept term $B_{0}=g\left(1-e^{h}\right)$ and the slope term $B_{1}=e^{h}$.

The linear fit of Lower Cold Creek flows on Upper Cold Creek flows is a good one, with $\mathrm{R}$-squared $=0.99$ and the residuals appearing to satisfy the underlying statistical assumptions (Figure 6). Both coefficients were significant, with p-values $<0.01$. The estimate of $B_{1}, 0.8624$, results in $h=-0.148$. Dinicola (1997) observed that most infiltration above Lower Cold Creek gage probably takes place in approximately the last mile, where alluvium begins to thicken appreciably, so channel reach length $x$ was set to $2000 \mathrm{~m}$. Field inspection suggested an average channel width $w=7 \mathrm{~m}$ for this reach. Therefore, $k=1.057 \mathrm{e}-5$, and $c=1.307$. Since no paired hydrographs were available for Dry Creek, the Cold Creek infiltration parameters $k$ and $c$ were applied to Dry Creek for predicting runoff in the design storm events. 
Table 3. Runoff Events for Calibrating Channel Infiltration Model

\begin{tabular}{|c|c|c|c|c|c|c|c|c|}
\hline Event & $\begin{array}{l}\text { Upper } \\
\text { Cold ID }\end{array}$ & $\begin{array}{l}\text { Upper } \\
\text { Cold Cr. } \\
\text { Mean } \\
\text { Flow Rate } \\
\text { (cfs) }\end{array}$ & $\begin{array}{l}\text { Upper Cold } \\
\text { Cr. Flow } \\
\text { Volume } \\
\left(\mathbf{m}^{3}\right)\end{array}$ & $\begin{array}{l}\text { Lower } \\
\text { Cold ID }\end{array}$ & $\begin{array}{l}\text { Lower } \\
\text { Cold Cr. } \\
\text { Mean } \\
\text { Flow } \\
\text { Rate (cfs) }\end{array}$ & $\begin{array}{l}\text { Lower Cold } \\
\text { Cr. Flow } \\
\text { Volume }\left(\mathbf{m}^{3}\right)\end{array}$ & $\begin{array}{c}\text { Infiltration } \\
\left(\mathbf{m}^{3}\right)\end{array}$ & $\begin{array}{c}\% \\
\text { Loss }\end{array}$ \\
\hline 1 & UC1 & 76.3 & 178803 & LC1 & 85.9 & 144484 & 34319 & 19 \\
\hline 2 & $\mathrm{UC2}$ & 39.1 & 57837 & LC2 & 44.5 & 28369 & 29468 & 51 \\
\hline 3 & UC3 & 14.9 & 15944 & LC6 & 1.6 & 1643 & 14301 & 90 \\
\hline 4 & UC4 & 35.8 & 36537 & LC3 & 33.2 & 16101 & 20436 & 56 \\
\hline 5 & UC8 & 5.9 & 32220 & LC7 & 5.3 & 11856 & 20364 & 63 \\
\hline 6 & UC5 & 58.4 & 110078 & LC4 & 39.6 & 73657 & 36421 & 33 \\
\hline 7 & UC6 & 48.0 & 92962 & LC5 & 56.2 & 54431 & 38531 & 41 \\
\hline 8 & UC7 & 12.3 & 25382 & LC8 & 4.3 & 7495 & 17887 & 70 \\
\hline \multicolumn{9}{|c|}{$\begin{array}{l}\text { UC8 begins on } 1 / 31 / 95-0400 \text { and ends on } 2 / 1 / 95-0000 \\
\text { LC6 begins on } 1 / 13 / 95-2245 \text { and ends on } 1 / 14 / 95-0830 \\
\text { LC } 7 \text { beings on } 1 / 14 / 95-1800 \text { and ends on } 1 / 15 / 95-1545 \\
\text { LC } 8 \text { begins on } 1 / 31 / 95-0700 \text { and ends on } 2 / 1 / 95-0000\end{array}$} \\
\hline
\end{tabular}

Lane et al. (1985) also tested a channel infiltration model with a shape term, where shape was defined by the SCS double-triangle hydrograph (see Section 4.2). Here, the model fit with a shape term was only marginally better than the simple linear regression, and therefore it was not used.

Equations 2-4 consider the total runoff volume for an isolated event and assume that baseflow and time-dependency of flow rate are negligible. In other words, the event is treated as single plug of runoff volume moving downstream, with no explicit consideration of hydrograph shape, antecedent channel conditions, or other transient characteristics. For most runoff events in arid, ephemeral streams, these are reasonable assumptions. 

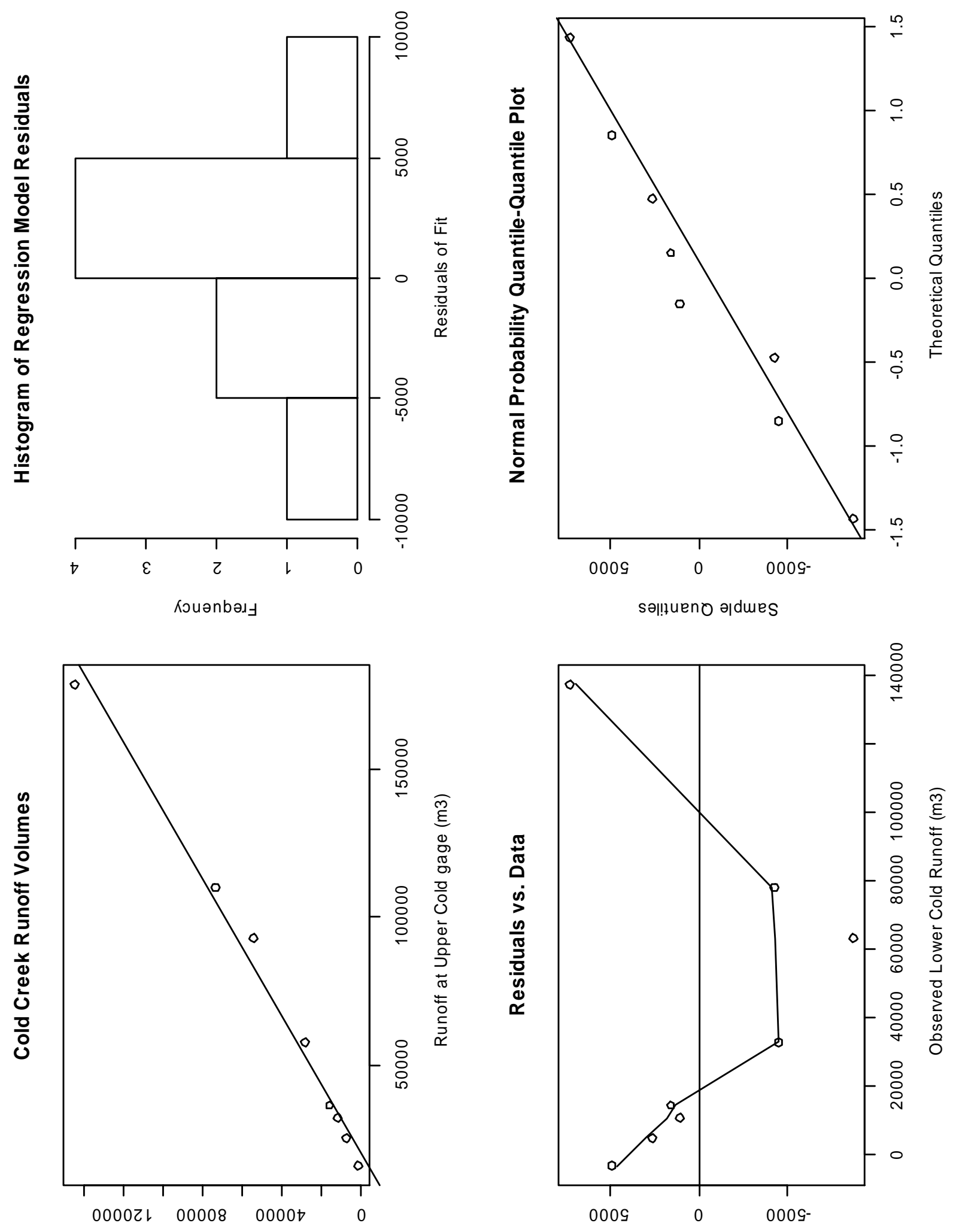

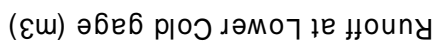

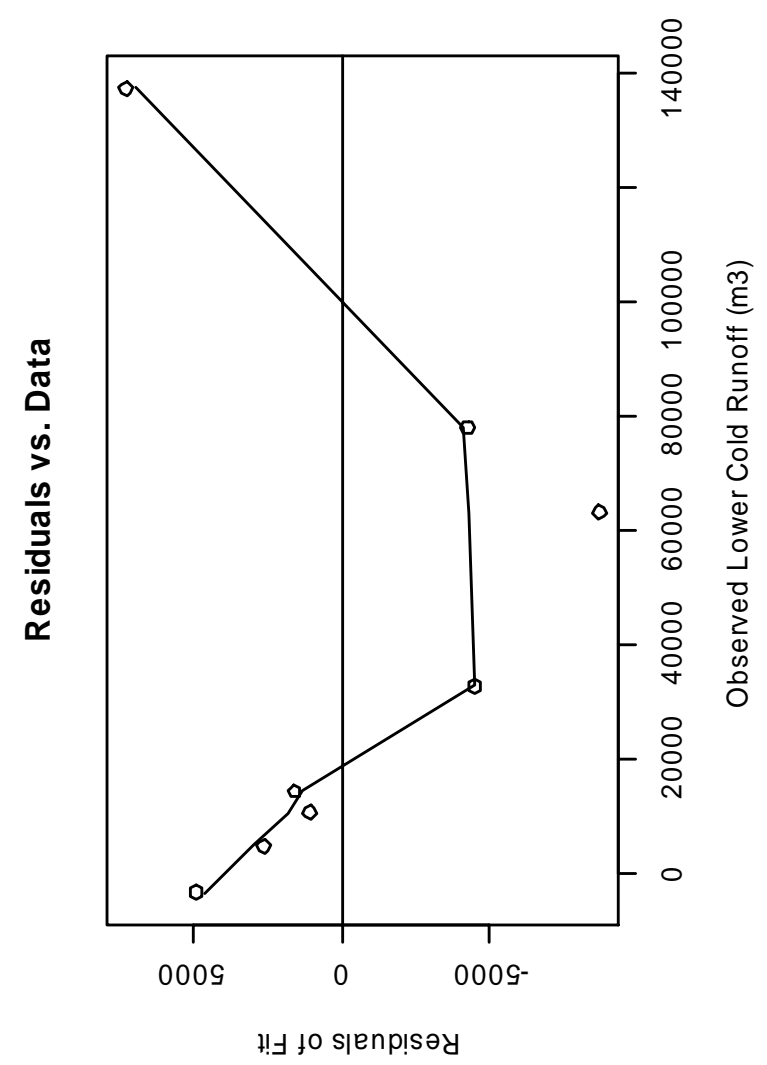

Figure 6. Cold Creek Runoff Volumes and Simple Linear Regression Model (source: regress.ps) 


\subsection{Double-triangle Hydrographs}

The SCS double-triangle hydrograph concept was used to determine the shape of the design storm hydrographs. Estimated peak flow rates follow from a pre-determined hydrograph shape. As described in Lane et al. (1985), the dimensions of the double-triangle hydrograph are defined by the following: 1) total volume $(=\mathrm{V}), 2$ ) duration (base of triangle) (=D), 3) fraction of duration to time of peak $(=a), 4)$ fraction of flow duration to time of inflection point on the recession limb $(=b)$, and 5) fraction of peak flow that is flow rate at inflection point $(=c)$ (Figure 7). Peak flow can be determined from these five independent variables.

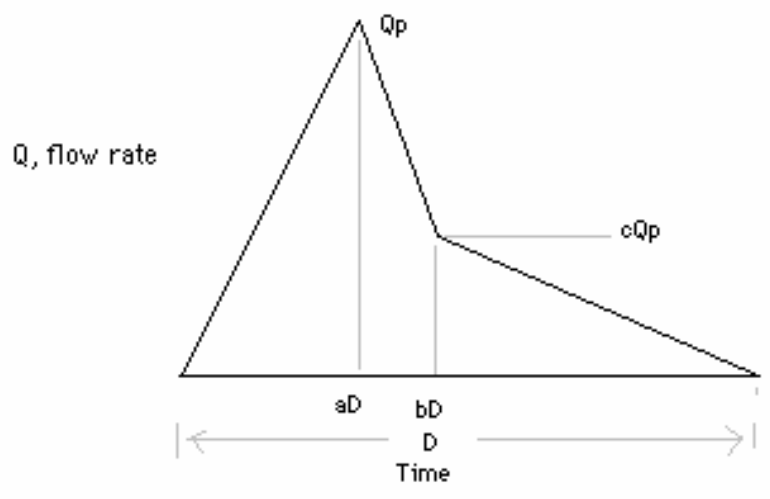

Figure 7. SCS Double-Triangle hydrograph

For each runoff event, the beginning time was defined as 15 minutes before the first increase in flow, and the end time was defined as 15 minutes after the last 15-minute positive flow value. This assumption allowed a designation of zero flow at the end and beginning, which simplified the model fitting process. The duration (D), peak flow rate (Qp), and fraction to time of peak (a) were determined from the data. Parameters $b$ and $c$ were then determined by trial-and-error to give the best double-triangle fit to the observed hydrograph. The parameter set that provided 5 percent error or less in total runoff volume and highest efficiency statistic was chosen. The statistic used was the modified coefficient of efficiency, E1, a first-degree statistic similar in purpose to R-squared but more stringent (Legates and McCabe 1999).

The fitted double-triangle hydrographs are good approximations of the data in many events (Figure 8). Shapes are similar between basins, but variability in factors such as antecedent conditions and rainfall excess duration resulted in coefficients of deviation $(\sigma / \mu)$ ranging from 19 to 55 percent for the three parameters a, b, and c. For simplicity, the mean values were used in subsequent modeling: $a=0.063, b=0.316$, and $c=0.235$. A runoff event with shorter duration and higher peak flow will tend to travel further downstream, distributing more of the recharge volume further from the source. 

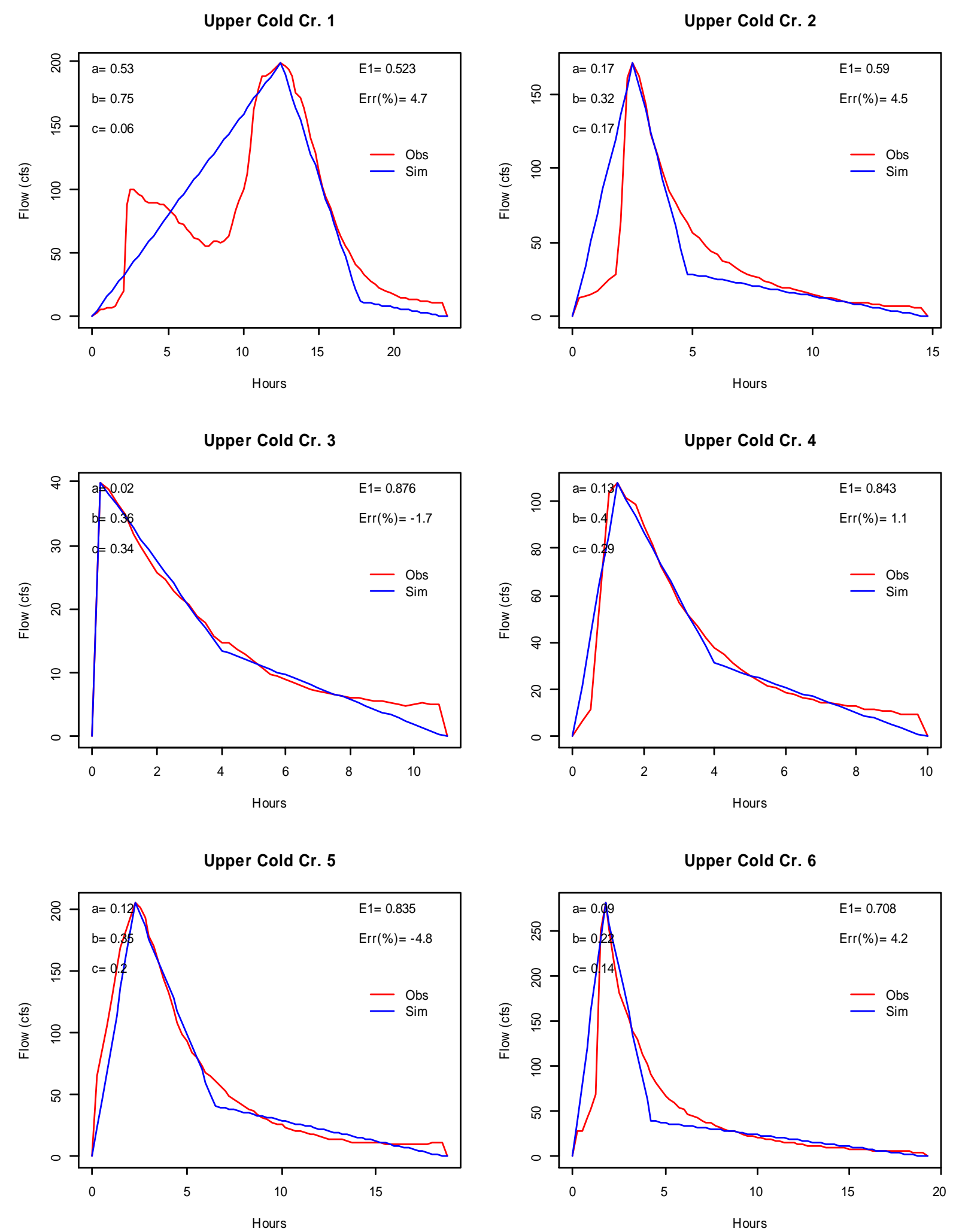

Figure 8. Observed and Fitted Double-Triangle Hydrographs, Selected Runoff Events 
Upper Cold Cr. 7

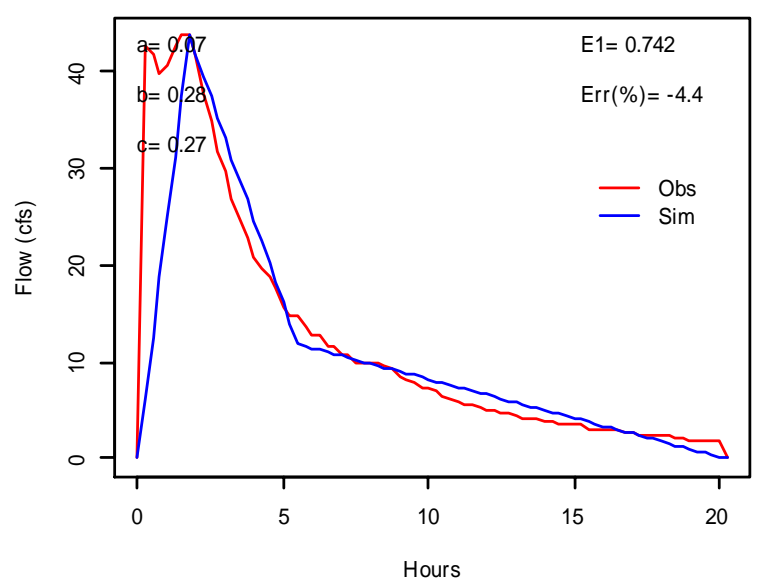

Lower Cold Cr. 2

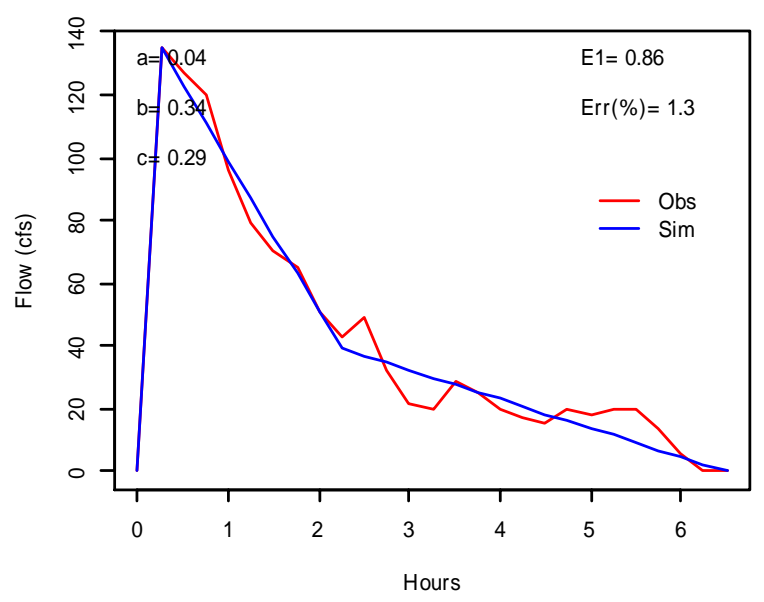

Low er Cold Cr. 4

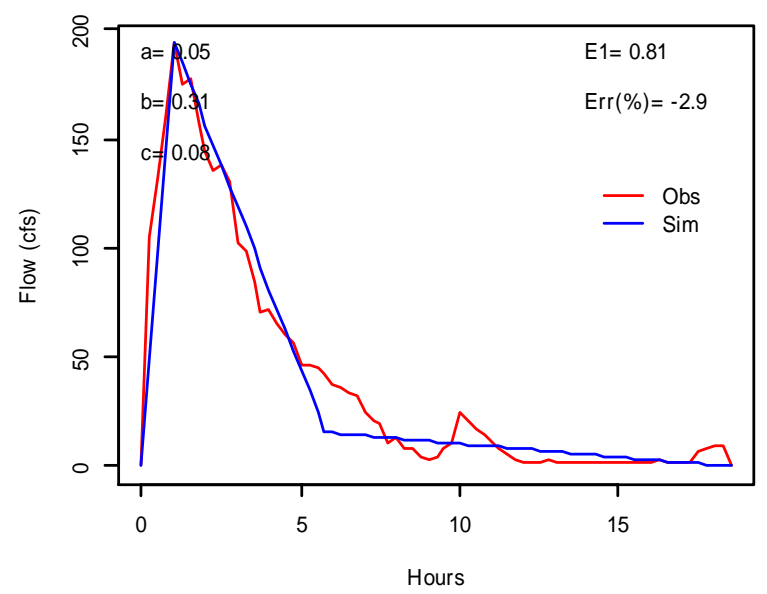

Lower Cold Cr. 1

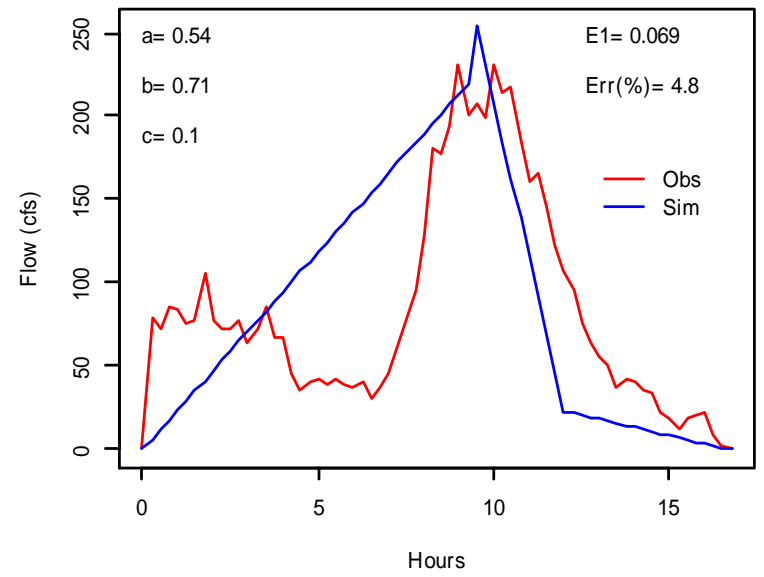

Lower Cold Cr. 3

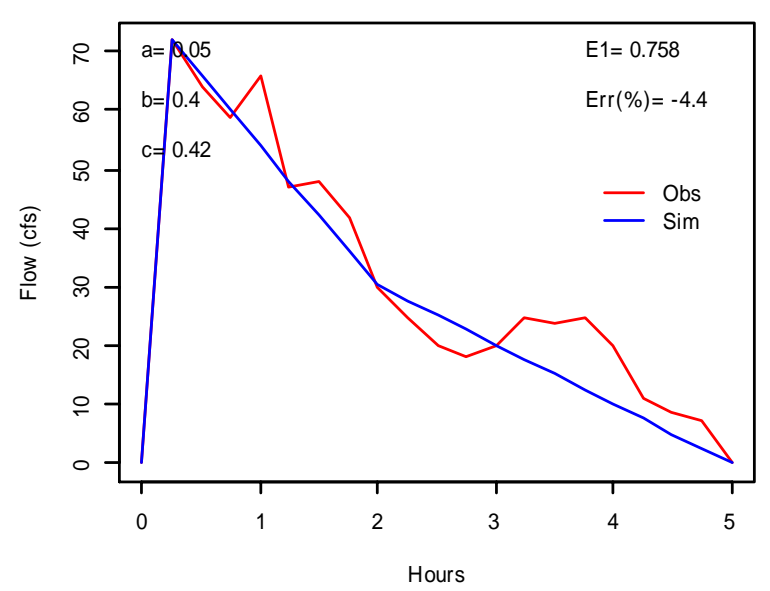

Lower Cold Cr. 5

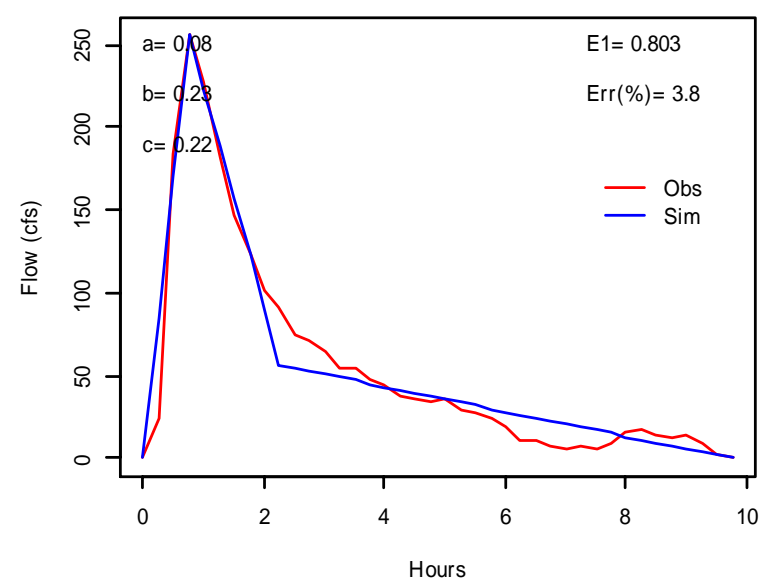

Figure 8. (cont'd) 

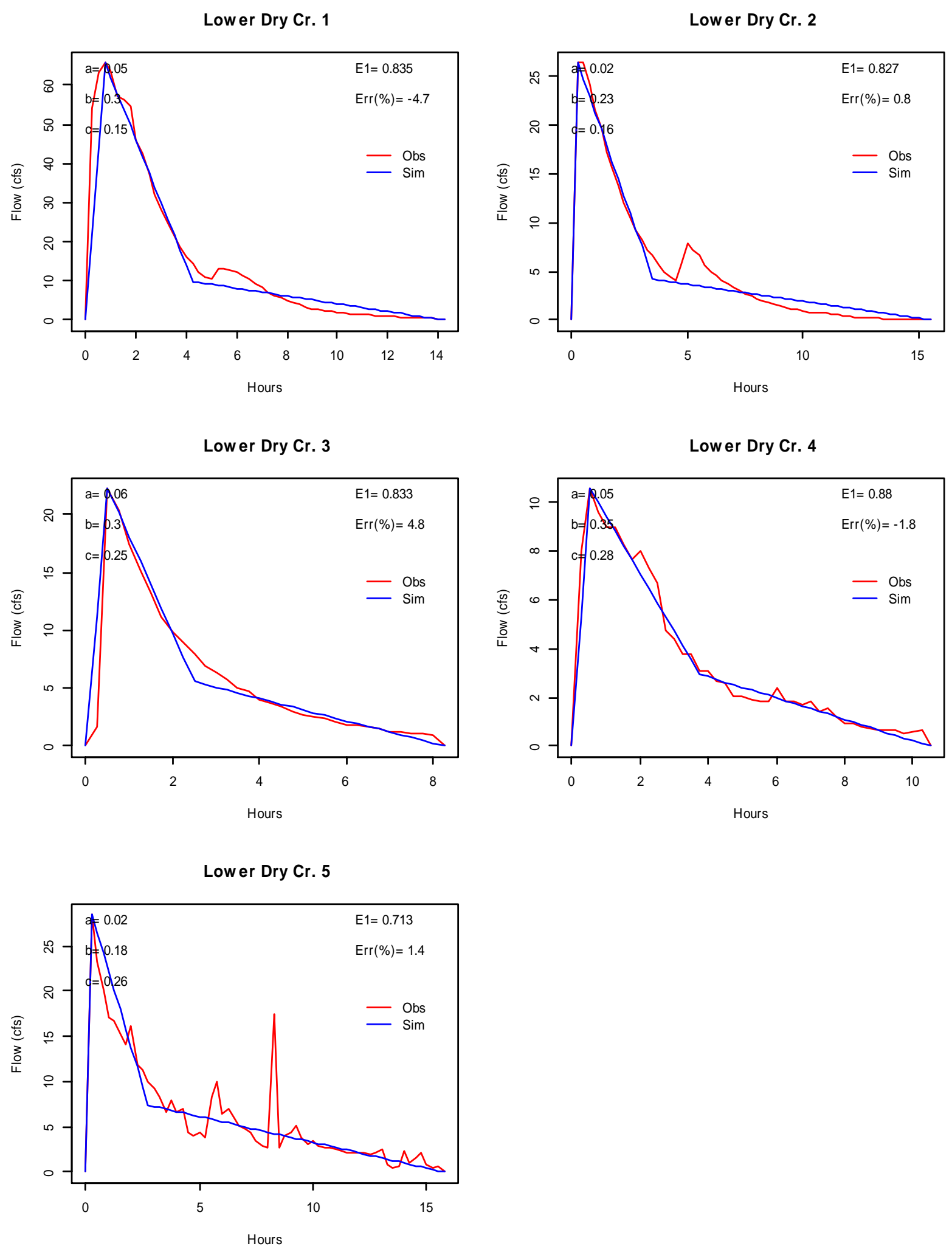

Figure 8. (cont'd) 


\subsection{Design Storm Events}

Design storm events were simulated in the following steps: 1) gather statistical estimates of extreme precipitation, 2) apply curve numbers from January 1995 data, and 3) route the runoff through Cold and Dry Creeks. The following assumptions were made for the runoff routing: 1) no infiltration in the upper basins, 2) infiltration and lateral inflow in the middle basins, and 3 ) infiltration only in the lower basins. The possibility of lateral inflow in the middle reaches was allowed because of the much larger precipitation in the design storms compared to the January 1995 events. No lateral inflow was assumed along the lower reaches because of the deep alluvium and gentle slopes compared to the middle and upper basins.

\subsection{Precipitation and Streamflow Generation}

Four hypothetical rainfall events were simulated: 6-hour probable maximum precipitation (PMP) from Skaggs and Walters (1981) and 100-year 24-hour, 100-year 3-day, and 100-year 7-day precipitation from Wigmosta and Guensch (2005). The PMP value is by far the largest, at 4.6 inches. The other values range from 1.61 to 2.71 inches. ( Table 4). In comparison, the largest precipitation event during January 1995 was 1.02 inches. This storm caused the largest observed runoff events at all gages.

Curve numbers for simulating the design storms were taken from the mean values in Table 2. Curve numbers for simulating the observed events (flows UC1, LC1, LD1) were the calculated

point values for those events. For the observed events in middle Cold Creek basin and upper Dry Creek basin, $\mathrm{CN}=66$, a low number corresponding to no runoff for those basin events.

Lower Dry Creek channel widths (below gage LD) were adjusted somewhat to yield runout lengths for LC1 and LD1 events that were consistent with Dincola's field observations. Low gradients and nearly level ground caused large overflow ponds to form $16 \mathrm{~km}$ downstream from UC and $19 \mathrm{~km}$ downstream from UD in those events, with minor flow reaching a couple of kilometers farther downstream at both locations. The maximum runout distances of the design storms are only marginally longer because the large channel widths assumed in these areas causes large streamflow loss to infiltration (Table 4). Runout lengths and associated recharge distributions are sensitive to the width assumed. 
Table 4. Simulation Results

\begin{tabular}{|c|c|c|c|c|c|c|c|c|c|}
\hline Basin & $\begin{array}{c}\text { Upper } \\
\text { CN }\end{array}$ & $\begin{array}{c}\text { Middle } \\
\text { CN }\end{array}$ & Rain Event & $\begin{array}{l}\text { Rainfall } \\
\text { (in.) }\end{array}$ & $\begin{array}{c}\text { Flow } \\
\text { Duration } \\
\text { (hrs) }\end{array}$ & $\begin{array}{c}\text { Upper } \\
\text { Gage } \\
\text { Runoff } \\
\text { Volume } \\
\left(\mathrm{m}^{3}\right)\end{array}$ & $\begin{array}{c}\text { Upper } \\
\text { Gage } \\
\text { Runoff } \\
\text { Volume } \\
\left(\mathbf{m}^{3}\right)\end{array}$ & $\begin{array}{c}\text { Total } \\
\text { Recharge } \\
\text { (acre- } \\
\text { feet) }\end{array}$ & $\begin{array}{c}\text { Runout } \\
\text { Distance } \\
\text { from } \\
\text { Upper } \\
\text { Gage } \\
\text { (km) }\end{array}$ \\
\hline ColdCreek & 80 & 66.2 & UC1,LD1 & 1.02 & 18 & $1.68 \mathrm{E}+05$ & $1.28 \mathrm{E}+05$ & 137 & 16 \\
\hline ColdCreek & 96 & 91 & 6-hourPMP & 4.6 & 15 & $7.78 \mathrm{E}+06$ & $8.58 \mathrm{E}+06$ & 8066 & 18 \\
\hline ColdCreek & 96 & 91 & 100-year24hours & 1.61 & 17 & $2.26 \mathrm{E}+06$ & $2.36 \mathrm{E}+06$ & 2236 & 18 \\
\hline ColdCreek & 96 & 91 & 100-year3days & 2.16 & 22 & $3.25 \mathrm{E}+06$ & $3.47 \mathrm{E}+06$ & 3276 & 18 \\
\hline ColdCreek & 96 & 91 & 100-year7days & 2.71 & 33 & $4.27 \mathrm{E}+06$ & $4.61 \mathrm{E}+06$ & 4340 & 18 \\
\hline DryCreek & 66.2 & 83 & UC1,LD1 & 1.02 & 18 & $1.81 \mathrm{E}-06$ & $7.24 \mathrm{E}+04$ & 480 & 22 \\
\hline DryCreek & 90 & 93 & 6-hourPMP & 4.6 & 15 & $1.31 \mathrm{E}+07$ & $6.39 \mathrm{E}+06$ & 22879 & 23 \\
\hline DryCreek & 90 & 93 & 100-year24hours & 1.61 & 17 & $2.88 \mathrm{E}+06$ & $1.48 \mathrm{E}+06$ & 5447 & 23 \\
\hline DryCreek & 90 & 93 & 100-year3days & 2.16 & 22 & $4.61 \mathrm{E}+06$ & $2.34 \mathrm{E}+06$ & 8456 & 23 \\
\hline DryCreek & 90 & 93 & 100-year7days & 2.17 & 33 & $6.44 \mathrm{E}+06$ & $3.23 \mathrm{E}+06$ & 11602 & 23 \\
\hline
\end{tabular}

\subsection{Groundwater Recharge from Channel Infiltration}

Total recharge volumes range from 2,200 to 11,500 ac-ft for the 100-year design storms, compared to just 137 and 480 ac-ft for the UC1 and LD1 events, respectively (Table 4). In Cold Creek, streamflow and recharge volumes were largest just above the lower gage. In contrast, runoff volumes in Dry Creek were largest at the upper gage, and recharge volumes are greatest in the ponding area downstream from the lower gage ( Figure 9).

Combined Cold Creek and Dry Creek recharge volumes for the 100-year rainfall events are: 1) 7,700 ac-ft, 24-hour, 2) 11,700 ac-ft, 3-day, and 3) 15,900 ac-ft, 7-days. For comparison, these recharge volumes are 7 to 14 times the average annual recharge rate for surface runoff estimated by Dinicola (1997), and fall between two estimates of direct recharge from infiltrating rainfall and snowmelt for the entire Hanford Site: 6,680 ac-ft/y (Fayer and Walters 1995) and 14,467 ac-ft/y (Jacobsen and Freshley 1990). The recharge volumes estimated here are less than half of those by Wigmosta and Guensch (2005) because that study used the entire Cold Creek basin down to the Yakima River as the area basis for computing runoff. Here, the focus was on recharge that originates tens of kilometers away and infiltrates in a relatively concentrated area on the Hanford Site. This study also focused on Cold and Dry Creeks because runoff events have been observed relatively frequently, and data were available there. It is possible that the high rainfall rates of the 100-year events would cause streamflow in other ephemeral channels, such as on the flanks of Rattlesnake Mountain, and cause significant distributed recharge by direct infiltration of the precipitation. 
ColdCreek Runoff Volume

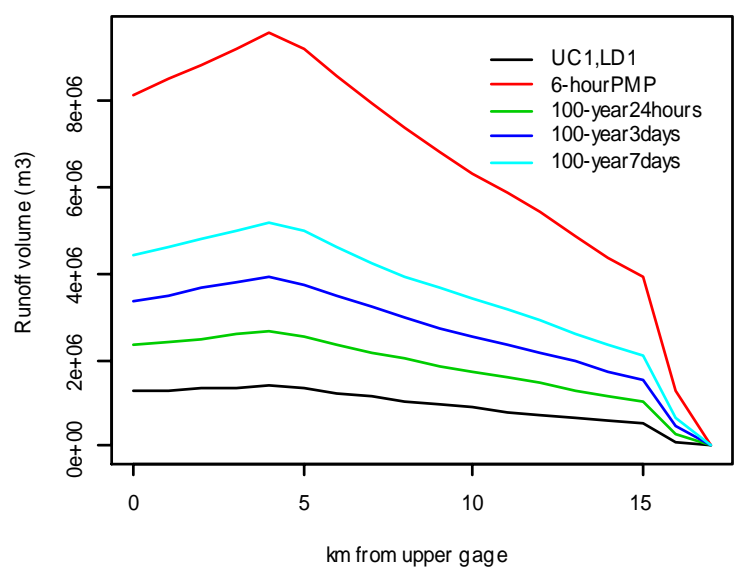

ColdCreek Peak Flow

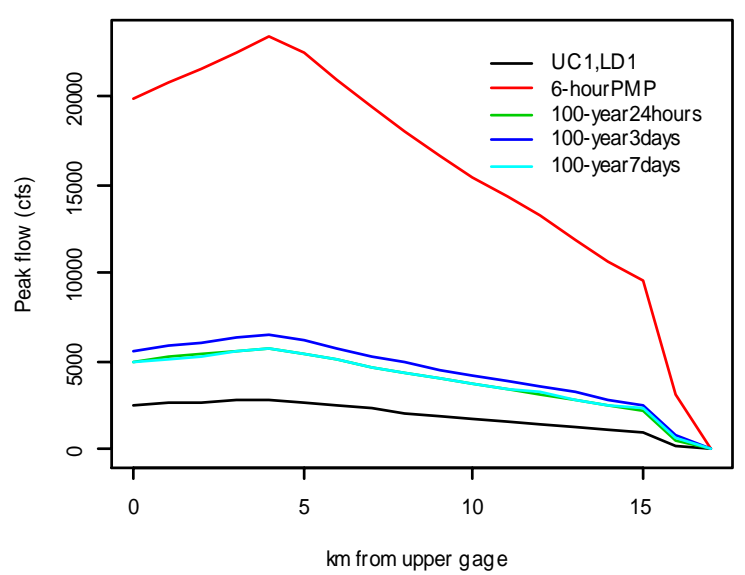

DryCreek Recharge Volume

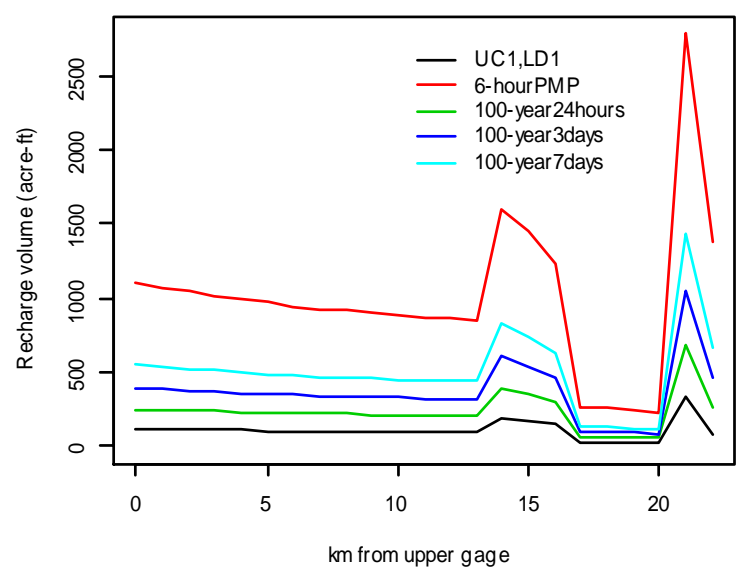

ColdCreek Recharge Volume

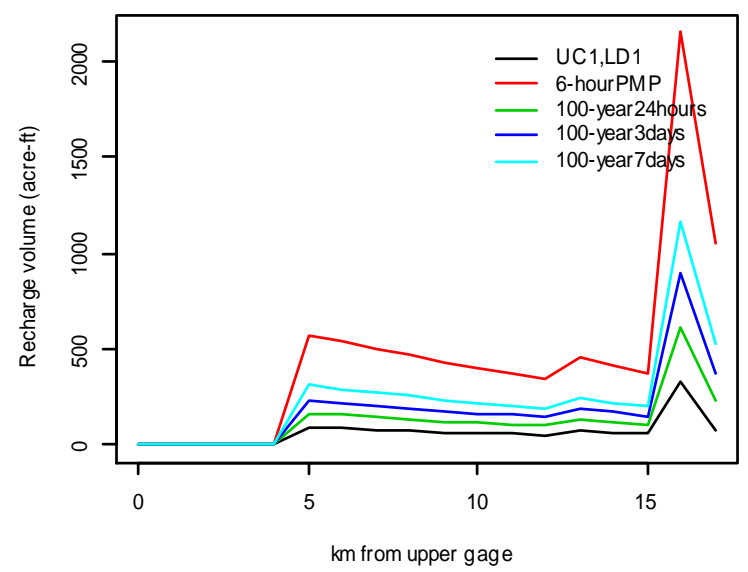

DryCreek Runoff Volume

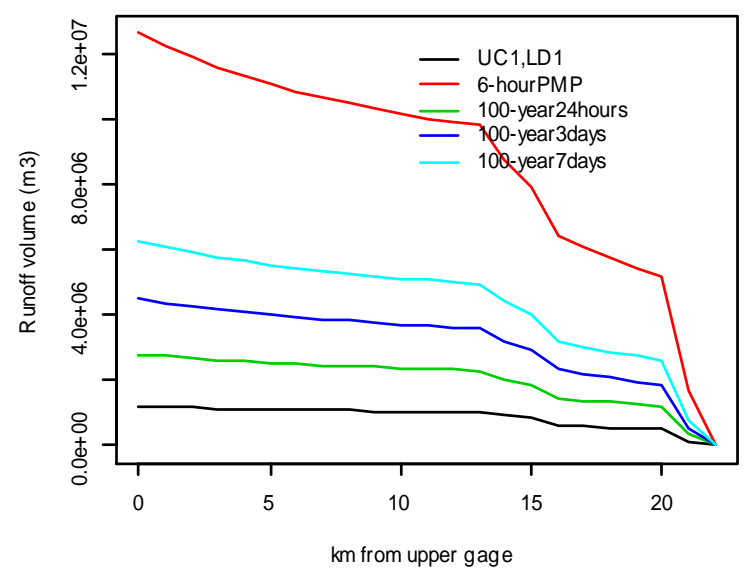

DryCreek Peak Flow

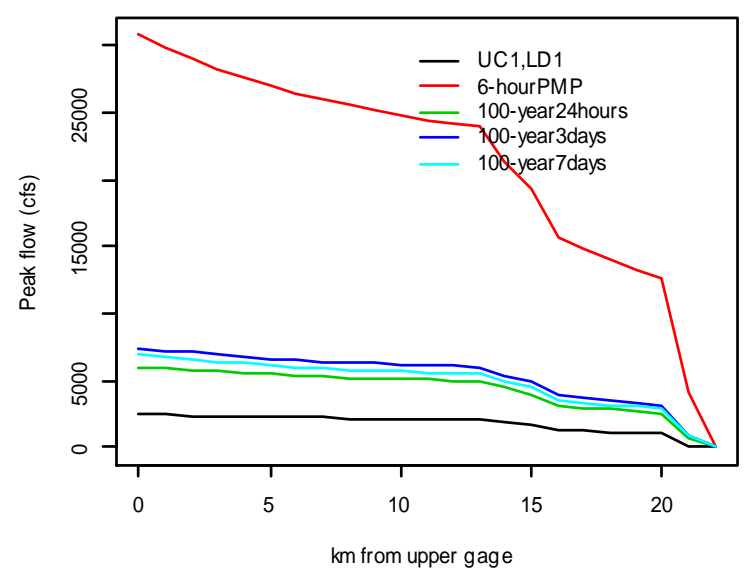

Figure 9. Runoff, Recharge, and Peak Flow vs. Distance 


\subsection{Discussion}

There are many uncertainties in the modeling approach described here, mainly because the design storm conditions are extreme in comparison to the observed events. High sensitivity coupled with high uncertainty of the key model parameters is another difficulty with a simple approach like the one used here.

Extreme precipitation estimates are uncertain because of relatively short climate records and because the distribution of precipitation in the mountainous areas away from HMS is poorly known. Curve number estimates are highly dependent on antecedent soil moisture and weather conditions, and as Wigmosta and Guensch (2005) noted, the curve number approach assumes that the probabilities of runoff generation and precipitation are the same. The channel infiltration parameters for both basins were obtained by fitting Cold Creek events alone, and the distribution of channel widths was roughly estimated from spot field checks. The actual infiltration parameters during large flow events such as the design storms may be less because storage in the riparian aquifer could fill up, causing further recharge to be shifted downstream. To improve this study, a sensitivity analysis of the runoff and recharge modeling is suggested (the computer code was designed to facilitate this). Depending on available resources, the estimated inputs to the model could be improved from more field study, or a more terrain-sensitive model such as DHSVM (Wigmosta et al. 1994) could be used to provide more constraints on the predictions. 


\subsection{Conclusions}

Streamflow measured at 15-minute intervals during January 1995 by the USGS provided an excellent opportunity to study ephemeral runoff and streamflow in Cold and Dry Creeks, a potentially important source of recharge to the Hanford unconfined aquifer. Streamflow hydrographs from storm events during that month were characterized by very rapid rise and almost equally rapid recession. A linear relationship was found between runoff volume at Upper Cold and Lower Cold gages, and that relationship was used to fit a simple exponential-decay channel infiltration model. SCS curve numbers were computed from runoff volumes at four gaging stations and precipitation measurements at the HMS. Estimates of total recharge volume were sensitive to precipitation and curve number. Groundwater recharge from Cold and Dry Creek runoff in extreme precipitation events may be ten times greater than the average annual recharge from this source. The predicted distribution of recharge along the stream channels is sensitive to assumed channel width, lateral inflow, and an exponential coefficient that represents infiltration rate. For better estimates of total recharge volume, it would be desirable to consider spatial characteristics such as variable terrain and climatology, and temporal characteristics such as antecedent soil moisture and frozen ground. For better estimates of recharge location, it would be necessary to consider stream channel characteristics more carefully, especially channel width, bank-full stage heights, bank-full flow capacities, and channel bed and floodplain permeability. A distributed watershed model such as DHSVM could be coupled with a flowrouting and infiltration model to develop more refined estimates of runoff and groundwater recharge. 


\subsection{References}

Dinicola, RS. 1997. Estimates of Recharge from Runoff at the Hanford Site, Washington, U.S. Geological Survey, Water-Resource Investigations Report 97-4038, 172 p.

Fayer, MJ and TB Walters. 1995. Estimates of Recharge Rates at the Hanford Site: Richland Washington, PNL-10285, Pacific Northwest Laboratory, Richland, Washington.

Jacobson, EA and MD Freshley. 1990. An Initial Inverse Calibration of the Groundwater Flow Model for the Hanford Unconfined Aquifer. PNL-7144, Pacific Northwest Laboratory, Richland, Washington.

Lane, LJ, WD Purtymun, and NM Becker. 1985. New Estimating Procedures for Surface Runoff, Sediment Yield, and Contaminant Transport in Los Alamos County, New Mexico, LA-10335-MS, Los Alamos National Laboratory, Los Alamos, New Mexico.

Legates, DR, and GJ McCabe. 1999. "Evaluating the Use of 'Goodness-of-Fit' Measures in Hydrologic and Hydroclimatic Model Validation," Water Resources Research 35(1), pp. 233-241.

Soil Conservation Service. 1972. National Engineering Handbook, Section 4, Hydrology.

Skaggs, RL and WH Walters. 1981. Flood Risk Analysis of Cold Creek Near the Hanford Site, RHO-BWI-C-120, PNL-4219, Pacific Northwest Laboratory, Richland, Washington.

Wigmosta, MS and GG Guensch 2005. Progress Report On: Potential Groundwater Recharge from the Infiltration of Surface Runoff in Cold and Dry Creeks. PNNL-15534, Pacific Northwest National Laboratory, Richland, Washington.

Wigmosta, MS, LW Vail, and DP Lettenmaier. 1994. "A Distributed Hydrology-Vegetation Model for Complex Terrain.” Water Resources Research 30, 1665-1679. 



\section{Appendix}

Additional Project Data 
PNNL-15533

\section{Appendix}

\section{Additional Project Data}

This appendix provides further information regarding project files and completed tasks. The main project directory is located on the Pacific Northwest National Laboratory Hydronet at /projects/dhsvm/coldcr. All of the files produced for this report reside under that directory. Wigmosta and Guensch (2005) used the directory /home/gguensch/proj_cold_creek/ for their development of digital terrain files and related GIS coverages. In addition, Scott Waichler/Pacific Northwest National Laboratory has related email messages in a personal email folder.

Table A.1 lists the key files used for the second phase of work (this report). Wigmosta and Guensch (2005) denotes the file was created by Wigmosta and Guensch (2005). Table A.2 lists conversion factors used for basin area and flow calculations.

Table A.1. Project Files

\begin{tabular}{|c|c|}
\hline File & Purpose \\
\hline \multicolumn{2}{|l|}{ main directory } \\
\hline report1.doc & memo report (this file) \\
\hline report1.xls & some tables and figures used in report document \\
\hline work_log.txt & daily log of project work completed \\
\hline cold_dry_flow2.xls & main file for tables and figures of meteorological and flow data \\
\hline precipdat.xls & 7-day precip totals for 1958-1997 (Wigmosta and Guensch 2005) \\
\hline precip3h_recur.xls & 7-day precip graphs (Wigmosta and Guensch 2005) \\
\hline hms1995.xls & 1995 hourly met data for HMS, EOC, and RMTN stations \\
\hline *.dat & hourly met data in various stages of processing \\
\hline *.out & $\begin{array}{l}\text { raw data met data supplied by Ken Burke/PNNL for HMS, EOC, RMTN, YAKB, } \\
\text { and RSPG stations }\end{array}$ \\
\hline manning.xls & estimate of bank-full stream discharges at various Cold and Dry Creek locations \\
\hline process_hms_*.pl & Perl scripts for processing met data; mainly concerned with lapse rates \\
\hline promet.f & $\begin{array}{l}\text { Fortran source file that shows how Hanford Meteorological Service data are } \\
\text { formatted }\end{array}$ \\
\hline jan95_streamflows.txt & $\begin{array}{l}\text { 15-minute streamflow provided by USGS for January } 1995 \text { at Upper Cold, Lower } \\
\text { Cold, Upper Dry, and Lower Dry gages }\end{array}$ \\
\hline cal_dt.R & R script for fitting SCS double-triangle hydrographs \\
\hline dt_results.txt & tabular output from cal_dt.R \\
\hline cal_route.R & R script for calibrating the channel infiltration model \\
\hline route_runoff*.R & $\begin{array}{l}\text { R scripts for routing design storm flows using SCS curve numbers, SCS double- } \\
\text { triangle hydrographs, and channel infiltration model }\end{array}$ \\
\hline route_results.txt & tabular output from route_runoff.R \\
\hline route_runoff.ps & plot output from route_runoff.R \\
\hline access_permit.doc & Application to USFWS for field visit to ALE lands \\
\hline \multicolumn{2}{|l|}{ GIS directory (arc/) } \\
\hline project.apr & ArcView project file with various coverages \\
\hline gageswtrshd5 & subwatershed grid coverage (Wigmosta and Guensch 2005) \\
\hline gagescovsnp5 & subwatershed gage locations (Wigmosta and Guensch 2005) \\
\hline
\end{tabular}




\begin{tabular}{|l|l||}
\hline \multicolumn{2}{|c||}{ Table A.1. (cont'd) } \\
\hline \multicolumn{2}{|c||}{ Purpose } \\
\hline demal18fill2 & \multicolumn{1}{c|}{ DEM for entire area (Wigmosta and Guensch 2005) } \\
\hline hanford_dem_site.aml & AML script for processing Hanford area DEMs (Wigmosta and Guensch 2005) \\
\hline create_subwatershed_dems.aml & AML script for creating separate subwatershed DEMs \\
\hline count_gridcells.aml & $\begin{array}{l}\text { AML script for counting the number of cells in a subwatershed DEM (used for } \\
\text { determining the area) }\end{array}$ \\
\hline uppercold & DEM grid coverage for area above UC gage \\
\hline cold2 & DEM grid coverage for area between UC and LC gages \\
\hline lowercold & DEM grid coverage for area above LC gage \\
\hline upperdry & DEM grid coverage for area above UD gage \\
\hline dry3dry2 & DEM grid coverage for area between UD and LD gages \\
\hline lowerdry & DEM grid coverage for area above LD gage \\
\hline \hline
\end{tabular}

Table A.2. Conversion Factors for Cubic Feet Per Second to Basin Inches.

\begin{tabular}{|c|c|c|c|c|c|}
\hline Locations & $\begin{array}{c}\text { Dinicola's } \\
\text { Sub } \\
\text { Watersheds }\end{array}$ & $\begin{array}{l}\text { Area } \\
\left(\mathrm{mi}^{2}\right)\end{array}$ & $\begin{array}{c}\text { Area } \\
\left(\mathbf{f t}^{2}\right)\end{array}$ & $\begin{array}{c}1 \text { cfs }= \\
\text { In * basin } \\
\text { area/sec }\end{array}$ & $\begin{array}{l}\text { Conversion factor } \\
\text { from cfs Flow Rate } \\
\text { to Basin Inches Per } \\
\text { 15-minute Interval }\end{array}$ \\
\hline Above UC & Cold4, Cold3 & 28.7 & $8.0011 \mathrm{E}+08$ & $1.4998 \mathrm{E}-08$ & $1.3498 \mathrm{E}-05$ \\
\hline Between UC, LC & Cold2 & 10.6 & $2.9551 \mathrm{E}+08$ & $4.0608 \mathrm{E}-08$ & $3.6547 \mathrm{E}-05$ \\
\hline Above UD & Dry4 & 56.9 & $1.5863 \mathrm{E}+09$ & 7.5649E-09 & $6.8084 \mathrm{E}-06$ \\
\hline Between UD, LD & Dry3, Dry2 & 64.1 & $1.7870 \mathrm{E}+09$ & $6.7151 \mathrm{E}-09$ & $6.0436 \mathrm{E}-06$ \\
\hline
\end{tabular}

\section{Reference}

Wigmosta, MS and GG Guensch 2005. Progress Report On: Potential Groundwater Recharge from the Infiltration of Surface Runoff in Cold and Dry Creeks. PNNL-15534, Pacific Northwest National Laboratory, Richland, Washington. 


\section{Distribution}

No. of

Copies

\section{ONSITE}

6 Pacific Northwest National Laboratory

S Waichler (PDF) K9-36

M Wigmosta (PDF) K9-36

M Bergeron (PDF) K9-36

MJ Fayer (PDF) K9-33

Information Release Office (2) P8-55

Distr. 1 